\title{
Türkiye Türkçesinin Yazı Dili Olarak Kuruluşunda -IcI Ekinin Durumu
}

\section{The Place of Suffix -IcI in The Formation of Turkish as a Written Language}

\author{
Mustafa BALCI ${ }^{1}$
}

${ }^{1}$ Sorumlu yazar/Corresponding author: Mustafa Balcı (Prof. Dr.)

İstanbul Üniversitesi, Edebiyat Fakültesi, Türk Dili ve Edebiyatı Bölümü, İstanbul, Türkiye

E-posta: mustafabalci@istanbul.edu.t ORCID: 0000-0003-3683-8705

Başvuru/Submitted: 05.10.2019 Revizyon Talebi/Revision Requested: 15.10.2019

Son Revizyon/Last Revision Received: 03.11.2019

Kabul/Accepted: 04.11.2019

Online Yayın/Published Online: 13.12.2019

Atıf/Citation: Balci, Mustafa. "Türkiye Türkçesinin Yazı Dili Olarak Kuruluşunda -Icl Ekinin Durumu." Türkiyat Mecmuasi-Journal of Turkology 29, 2 (2019): 367-390.

https://doi.org/10.26650/iuturkiyat.658900 öz

Oğuzların Selçuklu hâkimiyeti ile birlikte geniş bir coğrafyaya yayılmaları ve kitleler hâlinde yeni bir dini kabul etmeleri birbirine yakın zamanlarda olmuştur. Bölgede yaygın olarak kullanılan Farsça devlet dili olarak kullanılmaya devam etse de geniş Oğuz kitleleri için ihtiyaç duyulan din bilgisine cevap verecek kılavuz veya kaynak kitapların Türkçe ile yazılmasını gerektirmiştir. Illk dönem metinlerinde dinî muhtevanın ağır basması da bu ihtiyacın bir göstergesidir. Medreselerde okuyan genç Oğuzların toplumlarına geri döndüklerinde çevreye dinlerini anlatma istekleri, konuştukları dil ile metin üretme arzusunu da beraberinde getirmiştir.

İslam dininin temel kaynak kitabı olan Kur'an-ı Kerim'in de Türkçe ile ifade edilme çabası da böyle bir arzu neticesinde ortaya çıkmıştır. Kur'an'ın en doğru şekilde anlaşılması ciddi bir sorumluluk getirmektedir. Bu itibarla Oğuzcanın yazı dili olmaması, Kur'an-ı Kerim'in de sıradan bir metin olmaması hassasiyetini yükseltmiştir.

Kur'an'da çok sık kullanılan ve Allah'a ait sıfatların da yapısını teşkil eden bazı kelime türlerinin Türkçede ifadesi özellikle Kur'an tercümelerinde özel bir çabayı gerektirdiği anlaşılmaktadır. Arapçanın kendine has unsurlarından olan ism-i fail, sıfat-ı müşebbehe ve mübalağalı ism-i fail yapıları, Türkçenin büyük oranda yabancısı durumundadır. Bu makalede, söz konusu Arapça yapıların Türkçede yaygın bir kullanım alanı olmayan (-Icl) ekiyle oluşturulan yeni unsurlarla karşılanma çabası işlenmektedir.

Anahtar kelimeler: Türkçe, Arapça, sıfat-ı müşebbehe, ism-i fail, mübalağalı ism-i fail, -lcl eki

\section{ABSTRACT}

The expansion of Oghuz Turks into larger lands under the Seljuk dominion, and their adoption of a new religion as large masses, took place in periods that are quite close to each other. Although the Persian language continued its influnce in the state apparatus as the official language, the writing of the religious sources to provide large masses of Oghuzs with the proper guidelines for religious practice in Turkish was also an expanding need. The predomination of religious content in the early period writings has been an indicator of this need. The enthusiasm of medrese students who wanted to inform other people about religion whenever 
they came back to their own communities, stimulated their desire to produce written texts in their spoken language. The endeavours to express the main source of Islam, the Quran, in Turkish also originated from such needs. The comprehension of the Quran in the most correct way brings such a serious responsibility. Therefore, the absence of a written Oghuz language resulted in greater worries about the Quran, for it was never an ordinary text.

It seems to be the case that the Turkish expression of certain types of words that were often used in Quran, and were formative of divine attributions, necessitated a special effort, particularly in those Quranic translations. Certain peculiar elements in the Arabic language, such as ism- fail (present participle), sıfat-ı müşebbehe and the exaggerative present participle forms are all alien to Turkish. In this article, we will be examining the endeavours to produce the correspondent Turkish elements with the suffix (-Icl), for these Arabic forms that were not in common use in Turkish.

Keywords: Turkish, Arabic, sıfat-ı müşebbehe, ism-i fail, exaggerative present participle, -Icl suffix

\section{EXTENDED ABSTRACT}

Translation, though concerning quite many scientific disciplines such as medicine, pharmacy, mathematics, physics, philosophy, history, linguistics etc., and many other areas concerning practical lives like politics, trade, literature; for the most part, deals with interlinguistic connections.

The interactions between Arabic and Turkish started to flourish after the Turks' adoption of Islam. The translations from Arabic to Turkish stemmed mainly from the need to learn about the religion of Islam. Oghuz Turkish, in its formation process as a written language, was also fulfilling such a demand. Hence, the texts with religious content seriously predominated the ones that were produced in the early periods.

The expansion of Oghuz Turks into larger lands under the Seljuk dominion, and their adoption of a new religion as large masses, took place in periods that are quite close to each other. Whereas the need for written correspondence in the state hierarchy was being fulfilled via Persian, it is obvious that Arabic or Persian would fall short of such a proper function in the case of spreading religious knowledge. For this reason, a small number of literate Turks went into the effort of producing texts in Turkish, which was the common spoken language among Oghuzs and other clans. One may argue that the endeavour to write in Turkish gradually spread towards the west, beginning in the Horasan region. The adoption of Islam by the Oghuzs, and the formation of a large state organization in a simultaneous way, both came into play in the flourishment of the Oghuz language in the written form. Though the need for an official language was met by correspondences that were being written in Persian, it was not sufficient for the learning of the new religion, and in corresponding the demand for knowledge, which came forward in various strata of society in differing proportions. The fact that Arabic was the language of the main religious source, and the official language being Persian was leading to a shortage of communication for the larges masses of Oghuzs, with both the state and religion. Though the official language, being Persian, did not constitute a serious problem for the people who did not have grave concerns about the state mechanism, their disconnection with religion was quite of an inconvenience.

Firstly expanding to the Horasan region, and up to the inlands of Anatolia afterwards, Oghuz settlements necessitated their meeting with the new religion, and re-organizing their lives in accordance with the two motives, along with adapting to a new geography. Except 
for the migrant settler masses, religious knowledge had become a necessity for the Oghuzs, who adopted a sedentary life in their daily practices. The fact that it was religious motives behind the transmission of knowledge from Arabic to Turkish aggravated the responsibility of the translators who shouldered it. Any mistake that was to be made in the translation of a literary text would at worst vitiate the aesthetic flavour of the text. However, the translation of a religious text obviously requires much more sensitivity. Hence, one should admit that it requires a very special effort in the translation of such issues as the faith and the attributions of Allah, which also shape one's conception of God. The Quranic translations that were produced with such a sensitivity as much served for the formation of the written Turkish as for the comprehension and teaching of the religion.

The young Turkish scholars, who did not know any other written sources other the Arabic ones, must have used Arabic as a guide during their translations. We should admit that the translation of Arabic expressions to a language that had been used in written form before, must have been very difficult. Especially, the translation of some peculiar Arabic phrases to Turkish correctly, required the utmost prudence, so as to understand the source of religion in the most correct way.

The underline translation method which was commonly used in the early periods, despite being a poor method for the phrases, was successful in producing comprehensible Turkish written texts. In the course of these translations, there were some peculiar elements in Arabic, such as ism-i fail (present participle), sıfat-1 müşebbehe and the exaggerative present participle, which were alien to Turkish to a great extent. Building the conception of God in accordance with the understanding of oneness (and unity), the Quran presents the idea of God as almighty andbenevolent, by often making use of the aforementioned peculiar expressions. It also uses those word structures in order to explain the condition of men in the face of orders and prohibitions to which it appeals in regulating human life. The suffix -IcI in Oghuz Turkish virtually seems to have taken on a very special task, so as to meet the peculiar expressions of Arabic in question. The suffix IcI, which did not usually come forward in the early years in Old Turkish and the Anatolian region, is now one of the most common elements, and it is one of the indicators of verb performers.

We know that the suffixes -GII and -GAn were being used for certain verb performers of Arabic in the Karakhanid and Khorezmian regions. Such a differentiation indicates the rising sensitivity in the Anatolian geography with regard to the translations of these aforementioned structures. It also shows that the written language in Anatolia developed quite separately from the Turkistan region. Although the Quranic translations that were written in Karakhanid and

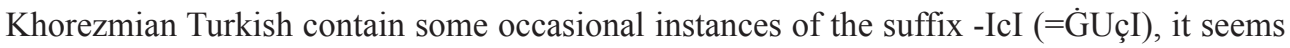
to have been used far less in proportion to the Anatolian region.

Besides the historical dialects such as Karakhanid and Khorezmian, there are some examples that it was from time to time corresponded by the suffixes -IcI (küçi and Kuçi) in Afghanistan Uzbek Turkish and Kazan Tatar Turkish. 


\section{Giriş}

\subsection{Tercüme ve Diller Arası Etkileşim}

Tercüme, bir metnin üretildiği dilden hedef dile aktarılırken tamamen tekrar kurulması ameliyesidir. Mütercim, müellif kadar belki ondan daha fazla emek harcayarak metni hedef dilin okurları için yeniden inşa eder. Tercüme süreci mütercimi bir yazar olarak da yetiştirir, terbiye eder, ustalaştırır. Kaynak dilde var olan güzelliği, letafeti, lezzeti belki korkuyu, dehşeti, nükteyi, hikmeti hedef dilde oluştururken aslında kaynak dilin inceliklerini fark edip hedef dilde var olan en uygun karşılığını bulmaya çalışır, olmayanı kaynak dildeki örneğe benzeterek türetmenin yollarını arar, kelimelere çağrışımlar yoluyla yeni manaların yüklenmesini sağlar. Kaynak dilden hedef dile yeni sözler taşır veya ihtiyaç duyulan anlamların hedef dilde oluşabilmesi için gayret sarf eder. Az kullanılan, az bilinen veya eskimiş kelimeleri yeniden gün yüzüne çıkardığı gibi az bilinen yapıları da yeni kelimelerin elde edilmesi için kullanır ve bunların canlı, yaygın bir yapı olarak gelişmesini sağlar.

Tercümeler diller arasında değiş̧ik metin türlerinin dolaşımına imkân verir. Bir dilde üretilen bilgi, araştırma, haber veya sanat metinleri bunlardan haberdar olanlar vasıtasıyla farklı dillerin konuşulduğu, okunup yazıldığı toplumlara tanıtılır. Çeşitli sebeplerle söz konusu metinlerin okunma ihtiyacı ortaya çıkar, var olan ihtiyaçlar çoğalır ve sözü edilen metinler her iki dili bilen kişilerce ehem-mühim ilişkisine göre bir dilden diğer dile aktarılır. Tercüme edilecek metinlerin başında ehemmiyet sırasına göre dini anlatan kitapların, risalelerin başta geldiği kabul edilmelidir. Çünkü din, insan ve toplum hayatını yönlendiren en önemli kurumdur. Bilgi içeren kaynaklar da (tıp, coğrafya, fen, matematik, astronomi, mantık vs.) tercüme edilme oranı bakımından üst sıralardadır. Daha sonra estetik zevke hitap eden metinler gelir.

Tercüme, kaynak dilden hedef dile sadece metin aktarmak değildir. Mütercim, kaynak dilde var olan mana ve anlatımı, his yoğunluğuyla birlikte, belki ses ve ahenk olgusunu gözeterek; bütün unsurlarıyla düşünerek hedef dilde inşa etmeye çalışır. Bilgi metinleri öğretme ve öğrenme amacıyla üretildiklerinden hitap ettiği kitle sınırlıdır. Estetik davranışı dışa vuran metinler ise değişken bir okur kitlesine sahiptir. Zaman zaman yüksek teveccühe mazhar olabildikleri gibi bazen de düşük sayıda okur tarafindan alaka görürler.

Tercüme metinler, esas olarak toplumların karşı karşıya kaldıkları yeni olguyu (din, öğreti, düşünce akımı, vs.) derinlemesine tanıma açısından en mühim araçlardan biridir. Söz konusu olgunun inşa olunduğu dili öğrenmek fertler için mümkün olabilir. Ancak bütün toplumun kaynak dili öğrenmesi mümkün değildir ayrıca buna gerek de yoktur. Dolayısıyla kaynaklara inme, yeni dini veya medeniyeti tanıma, bilme ve derinlemesine öğrenmenin yolu tercüme işine kapı aralamaktadır. Yeni karşıllaşılan ve tâbi olunan bir dinin veya öğretinin temel veya ikincil metinleriyle muhatap olan toplumların hayatlarında önemli değişimler, açılımlar gözlemlenir. Bütün bu gelişmeler, tercüme vasıtasıyla dil üzerinden topluma aktarılır. Toplumların medeniyet yolculuklarında yaşadıkları dönüşümler, dilleri takip edilerek anlaşılabilir. 
Tercümenin dinî saiklerin ağırlığı veya yönlendirici etkisi matbaanın yaygınlaşmasına kadar sürmüştür. Dinin matbaa ile birlikte toplum hayatındaki belirleyiciliği devam etse de edebiyat ve bilim dinî metinlerle koşutluk kazanmıştır. Matbaanın yaygınlaşmasına kadar devam eden süreçte dinin toplum hayatındaki belirleyici ve yönlendirici tarafının estetik metinlerde bile kendini gösterdiğini söylemek mümkündür. Türkiye Türkçesindeki kuruluş devri metinlerinde dinî muhtevalı şiirlerin yekûnu dikkate alınarak bahsi geçen mevzu daha yakından incelenebilir. Türkiye Türkçesinin kurucu şairi olarak kabul edilen Yunus Emre'nin Divan'1, Âlî'nin Klssa-i Yûsuf'u, Hamdullah Hamdî'nin Yûsuf u Zeliha'sı yanında Erzurumlu Darir'in, Süleyman Çelebi'nin ve diğer mutasavvıf şairlerin ürettiği metinlerdeki dinî duyarlığın varlığı bahsi geçen durumun göstergesi olarak zikredilebilir.

Tercümeler, hedef dile bilgi veya estetik değer taşırken yukarıda ifade edildiği gibi anlatım, cümle, söz varlığı, ses gibi farklı dil kategorilerinde de büyük gelişme ve genişlemelere imkân sunar. Edebî türleri zenginleştirdiği gibi hedef dili, söz konusu yeni metin şekilleri ve üslup çeşitlilikleriyle tanıştırır. Kaynak dilden gelen yeni imkânlar hedef dildekilerle birleşerek daha özgün ve farklı biçimlerin ortaya çıkmasını sağlayabilir.

İnsanlık tarihinde değişik zamanlarda milletleri etkileyen büyük tercüme faaliyetleri olmuştur. Yunan klasiklerinin Arapçaya tercümesi veya Endülüs üzerinden Arapçadaki birikimin Latinceye aktarılması bu kabîlden bir durumdur. Arapça ile etkileşimi olan bütün Müslüman topluluklar ve dilleri de kademe kademe bu dilden etkilenmiştir. Yunan klasiklerinin Arapçaya çevrilmesi ile Arap dilinde, belagatinde, dilcilik anlayışında, ifade kalıplarında ve yazın türlerinde (edebiyat ve sair yazılı metinler) gelişme, genişleme ve yüksek anlatım imkânları bakımından farklılaşmalar görülmüştür. Yunan klasiklerinin Arapçaya tercümesinin Arap diline ve edebiyatına katkıları için Akif Özdoğan'ın Aristo şarihlerinden biri olarak bilinen Şerif Cürcânî ve çalışmaları hakkında söyledikleri tercümelerle ortaya çıkan etkileşimin anlaşılmasını açıklar niteliktedir:

«el-Cürcânî "Esrârü'l-belâğa" adlı eserini telif ettiğinde Aristo’yu çok iyi yorumlayan, açıklayan felsefeci konumundaydı. Taklit nazariyesinin Araplarda özellikle de el-Cürcânî’de yansıması mecâz, teşbîh ve kinâye şeklinde olmuştur. el-Cürcânî, "Delâilü'l-i'câz adlı eserinde, güzelliğin cümlede, üslûpta olduğunu ifade ile cümleyi geniş olarak ele alır, atıf harflerinin manaya etkisinden bahseder. Aristo'nun dil ve belâgat ile ilgili görüşlerinden yararlanarak nahiv felsefesini ele aldı̆̆ı ve kendisinin de "meâni’n-nahv" ya da "nazm" dediği "meânî" ilmini sistemli bir şekilde kurmuştur. el-Cürcânî’ye göre nazm, sözün nazmı ile eşyalar arasında irtibat kurmaktır. Bu da nahiv ilminin kurallarını, sözde kullanmak ve tatbik etmekle gerçekleşir. Kelimeler tek başına fasih olmayıp ancak cümle içinde fasih ve beliğ olabilir. Sözün de beliğ olabilmesi için, nahiv kurallarına uygunluğu şarttır. Sözün nazmı ile eşya arasında irtibat yolları olarak gördüğü nahiv kurallarından atıf harfleri, takdîm-te'hîr, hazf, mübtedâ ve haberin hazfi, hal cümlesindeki vav'ın hazfi vb. konuların önemini vurgulayıp îcâz, itnâb, vasl, kasr ve muktezâ-yı hâli mana için gerekli görmüştür. Gramer ile belâgat 
kurallarını sentez yaptığı bu eserinde grameri, canlı, fonksiyonel ve pek çok anlam ifade eden bir ilim haline getirmiştir. ${ }^{1}{ }^{\prime}$

\subsection{Arapça ve Farsça Metinler Karşısında Türkçe}

Türkçe açısından bakıldığında tarihte birkaç büyük tercüme hareketi görülür. Geneli itibariyle dinî saiklerle ortaya çıkan tercüme ihtiyacı öncelikle Uygurların Buda, Mani, Brahma gibi dinleri kabul etmesinden sonra kutsal metinlerin Türkçeye aktarılması şeklinde kendini göstermiştir. Buda öğretilerinin büyük kısmını oluşturan bu tercümeler, Sanskritçe, Soğdca, Çince gibi dillerden yeni kelime ve kavramlarla birlikte farklı ifade şekillerini ve bunlara bağlı olarak cümle türlerini, değişik kelime ve cümle yapılarını da Türkçeye taşımış veya Türkçenin kendi imkânları ile birtakım yeni usulleri ortaya çıkarmasını sağlamıştır. İslamiyet'in kabulüyle Arapçadan ve Farsçadan yapılan tercümeler yine Türkçe için büyük gelişmelere imkân sağlamıştır.

Türk topluluklarının Arapça ve Farsça ile etkileşimleri İslamiyet'le karşılaştıktan sonra muhtelif coğrafyalarda farklı şekillerde kendini göstermiştir. Türklerin İslam dini ile tanışmalarından sonraki süreçte dinin doğru bir şekilde anlatılması ve iyi bir kul olmanın göstergesi olan ibadetlerin yerine getirilebilmesi için gerekli olan bilgileri ihtiva eden kitapların Türkçeye tercüme edilmesine ihtiyaç duyulmuştur. Söz konusu ihtiyacı karşılamak üzere İslam tarihi, siyer, hadis, fikıh, kelam, akaid gibi İslam dininin temel konularına ait kitapların yanında bizzat Kur'an-1 Kerim yani Allah'ın insanlara hitabı, Türkçe ile ifade edilme ihtiyacı olarak kendini göstermiştir. Karahanlı sahasında da aynı ihtiyaç hissedilmiş ve Batı Türkçesinden birkaç asır önce Kur'an'ın Türkçeye aktarılması tecrübe edilmiştir. Anadolu sahasında da Kur'an, yazılı tecrübesi çok olmayan ve yeni yeni kurulmakta olan yazı diline tercüme edilmiştir. Farslara yakın coğrafyada yaşayan Türk toplulukları İslam dinini ilk olarak adı geçen komşularından öğrenmiş olduklarından zaman zaman İslam'a dair metinlerin Farsçadan Türkçeye çevrildiği görülse de İslami kaynakların dili olmasından dolayı Arapçanın kaynak dil olarak ağırlığı tartışılmaz.

Türk toplulukları çok geniş bir coğrafyaya yayılmış olduklarından İslamiyet'le tanışmaları farklı zamanlarda olmuştur. Türkçe yazı dillerinin kuruluşunda devamlılığın olup olmadığı konusunda farklı görüşlerin ortaya çıkmasının sebepleri arasında söz konusu coğrafya genişliği ile birbirlerinden uzak ve dağınık yaşama durumunun varlığı sayılabilir. Söz konusu zaman ve zemin farklılıkları Arapçadan Türkçeye aynı metinlerin değişik dönemlerde çevrilmiş olmasını gerektirmiştir. İletişim şartlarının çok sınırlı olduğu dönemlerde yaygın eğitimöğretim imkânlarının bulunmayışı, üretilen tercüme veya telif eserlerin sadece muhataplarınca bilinmesi ve dar bir çevrede kalması neticesini doğurmuştur. Bundan dolayı İslam dininin temel metinlerinin farklı coğrafyalarda birbirinden habersiz mütercimler tarafindan Türkçeye

1 M. Akif Özdoğan, “Abbasîler Dönemi Tercüme Faaliyetlerinin Arap Edebiyatına Etkisi”, Nüsha Şarkiyat Araştırmaları Dergisi, 5/16 (2005). 
çevrilmesi ihtimal dâhilindedir. Söz konusu çevirileri üreten kişiler uzak coğrafyada cari olan bir yazı dilinden ve o yazı dilinin mevcut külliyatından haberdar olmadan bildiği yazı dilinin kılavuzluğunda (Arapça gibi) kendi konuştuğu dil ile telif veya tercüme yoluyla metinler üretmeye başlar. Böylece bilinen bir yazı dili (Arapça) kılavuzluğunda bir konuşma dili (Oğuz Türkçesinin bir ağzı) yazı diline dönüşebilir. Anadolu sahasında konuşulan Türkçenin bazı bölgelerde böyle bir yol takip etmiş olması ve Karahanlı-Harezm Türkçesinin varlığından habersiz kişilerce yazı dili olarak kullanılması kuvvetle muhtemeldir. İslam dininin en temel metni olan Kur'an-1 Kerim'in Türkçeye kuruluş devrinde çok farklı tecrübelerle tercüme edilmiş olması böyle bir ihtimali doğrular niteliktedir.

Türkçe Uygurların yaşadığı değişim ve dönüşümle birlikte başta din olmak üzere hukuk ve edebiyat alanlarında yetkinliğe ulaşmış ve Burkancı medeniyete katkılar sunan bir dil hâline gelmiştir. Eski Uygur Türkçesi olarak bilinen yazı dili Müslümanlığın kabulü ile birlikte Arap harfleriyle de yazılmaya başlanmıştır. Dolayısıyla var olan bir yazı dili Arap harfleriyle de kullanıldığından Uygur Türkçesinin İslamiyet’ten sonraki adı olan Karahanlı Türkçesi, Batıda kurulmakta olan yazı dili kadar acemilik yaşamamıştır. Anadolu sahasında gelişen Oğuzca temelli yazı dilinin Doğudaki tecrübeden faydalanıp faydalanmadığı veya ne kadar faydalandığ konuları tartışmalıdır. Metinler üzerinde söz varlığı, cümle çeşitliliği, kelime teşkilindeki gelişmeler ve benzeri konulara dair yürütülecek yeni çalışmalar bu tartışmalara yön verecektir.

\subsection{Kur'an Dili ve Türkçe}

Kur'an-1 Kerim, İslam dininin en temel kitabıdır fakat Arapça bilmeyenler için okunup anlaşılması sorun teşkil etmektedir. İslam'ın Arap olmayan toplumlar arasında yayılmasından sonra dinin temeli olan kitabın başka bir dile çevrilmesi tartışılmıştır ve güncel olarak da tartışılmaya devam etmektedir. ${ }^{2}$

Dinin en temel konularının, yasaklarının, ibadet şekillerinin, iman usullerinin belirlendiği; başka toplumların ibretlik hikâyelerinin anlatılıp farklı hükümlerin verildiği bir metnin kendi dilinde olduğu gibi bir anlam dünyasıyla hedef dilde inşası mümkün olamayacağı âlimler tarafından kesin bir dille ortaya konmuş ve tercüme konusu yasaklanmıştır. Din âlimlerinin yasaklarına rağmen girişilen tercüme ameliyesi, mütercimlerin nasıl müşkül bir işe kalkıştıklarını anlatması bakımından önemlidir. Bir başka tehlike dinin yanlış anlaşılmasına sebep olma ihtimalidir. Nihayet Kur'an'ın aktarıldığı dilde okunur ve anlaşılır bir metin hâline getirilmesi zarureti de önemli diğer bir sorundur.

Gerek Karahanlı döneminde gerekse daha sonraki dönemlerde ortaya konan Kur'an tercümeleri, bu tür manevi baskıların ağırlığı altında hazırlanmış olan metinlerdir. Uygurcanın devamı niteliğinde olan Karahanlı Türkçesi ile uğraşanların işi Oğuzca yazmaya çalışanlara göre kısmen kolay olsa da söz konusu kitap Kur'an-1 Kerim olduğu için tercüme sürecinde

2 Halil Altuntaş tarafından ayrıntılı olarak incelenen Kur'an'ın tercümesi meselesini Suat Ünlü, Karahanlı Türkçesi Illk Satır-Arası Kur'an Tercümesi (TIEM 73), (Konya: Eğitim Kitabevi, 2018), XVII-XIX adlı çalışmasında özetlemiştir. 
mütercimler ciddi zorluklar yaşamış olmalıdırlar. Kur'an metninin doğru anlaşılması meselesi mütercimler için aşılması gereken ilk zorluktur. İkincisi Kur'an'1n Arapça gibi Türkçeye tamamen uzak bir dille indirilmiş olmasıdır. Bu bağlamda Arapçanın dolayısıyla Kur'an'ın ifade şekline ve anlamına en uygun metnin oluşabilmesi için çok büyük çabalar sarf edilmesi gerekmiştir. Kur'an metninin çok yönlü anlatımı vardır. Bazen müjdeler bazen tehdit eder bazen de iman umdeleri, yaradılış hakikati gibi konularda bilgilendirir. Kur'an'ın farklı üsluplarını, mümkün olabilecek en iyi şekilde Türkçede oluşturma çabası, mütercimleri kendi dillerinde birtakım yenilikler ve ifade şekilleri bulmaya sevk etmiştir.

Kur'an-1 Kerim'in Arapçası, fiilleri icra edene önem veren bir dildir. Kur'an anlatımı, amelceza ilişkisini vurgulayan, fiilleri icra edenleri gösteren, zikreden ve dolayısıyla emirlere uyma ve yasaklardan uzak durmayı temel davranış olarak gösteren ifade şekilleri bakımından zengindir ${ }^{3}$. Arapçanın failleri gösteren ism-i fail, sıfat-ı müşebbehe ve mübalağalı ism-i fail gibi şekilleri, fiiller ve icracılarını merkeze alan zengin bir anlatım şeklinin varlığını ortaya çıkarmaktadır.

Türkçe, icra edeni, bir şahıs ekini fiile getirerek anlatan bir dil olduğundan fiilin icracısı için başka bır unsuru cümlelerde çok gerekmedikçe kullanılmaz. İhtiyaç durumunda bir özne zikretmek elbette Türkçede de mümkündür ama çok şart değildir. Kur'an metninde fiili icra edeni farklı şekillerde açıkça ifade eden yapıların nasıl tercüme edileceği konusu mütercimleri hayli uğraştırmıştır. Fiilleri icra edenin göreceği karşılığın amel-ceza-mükâfat ilişkisi bağlamında önemi ve metnin taşıdığı vurgunun aktarılması meselesinin mütercimleri uğraştıran bir başka unsur olduğu anlaşılmaktadır. Allah'ın sıfatlarının da ism-i fail, sıfat-1 müşebbehe veya mübalağalı ism-i fail olarak hedef dildeki ifadesi, mütercimin çözmesi gereken ayrı bir hassas meseledir.

Eski Anadolu Türkçesi Kur'an tercümelerinde fiil icracılarını gösteren yapıları ifade etmek ve Kur'an'ın anlatımından kaynaklanan farklılığı verebilmek için mütercimlerin ciddi çabalar sarf ettikleri görülmektedir. Bazı eklerle türetilen kelimelerde görülen yoğun kullanımdan Kur'an dilindeki ifade şekillerini yakalama çabası için özel alanlar oluşturulmaya çalışıldığı anlaşılmaktadır.

3 Fiil icracılarını imleyen yapıların Kur'an'dan önceki Arapçada yaygın bir şekilde kullanılıp kullanılmadı̆̆ı konusunda görüşlerine müracaat ettiğim sayın Prof. Dr. Mustafa Öztürk, ism-i fail, sıfat-1 müşebbehe, mübalağalı ism-i fail yapılarının Kur'an öncesi Arapçada çok yaygın bir kullanım alanına sahip olmadığını ifade etmiştir. Öztürk, iki temel saikten dolayı Kur'an-ı Kerim'de bu yapıların yoğun olarak kullanıldığını söylemiştir: ilki cahiliye Araplarının Tanrı algısında var olan deist anlayışı silip sahih bir ilah algısını oluşturmak için Allah, Rabbü'l-âlemin olduğunu, kâinatın işleyişinde bizzat fiilleriyle fail ve faal bir ilah olarak kendini Kur'an'da farklı fiillerle ilişkilendirerek tarif etmiştir. Allah'ın, Tevhid inancını inşa ederken, zatını tanıtırken, ayrıca insanın daima kendi gözetimi ve denetimi altında olduğunu anlatırken bu yapıların hâkim olduğu bir söyleyiş tarzının öne çıktığını belirtmiştir.

İkinci saik olarak da yukarıda zikredilen ceza-mükâfat ilişkisiyle ilgili görüşe iştirak etmiş ve fiilleri icra edenlerin ceza veya mükâfatla birlikte zikredilmelerinden kaynaklanan bir yoğunlaşmanın öne çıktığını söylemiştir. Öztürk, Kur'an-1 Kerim dışında Arapçada bu yapıların yoğun olarak kullanılmadığını ifade etmiştir. Sayın Öztürk'ün zikredilen son ifadesinden Kur'an anlatımının bu manada Arapçada bir etkisi olmadığı anlaşılmaktadır. Oysa Türkiye Türkçesinde -IcI eki, önceleri çok düşük kullanım alanına sahipken yukarıda izah edilen durumdan dolayı başta Kur'an olmak üzere İslâm dininin temel metinlerinin tercüme edilmesine koşut olarak en yaygın ve yoğun olarak kullanılan eklerden birine dönüşmüş durumdadır.

Vakit ayırıp kıymetli görüşlerini paylaşma lütfunda bulunduğundan dolayı Prof. Dr. Mustafa Öztürk’e teşekkür ederim. 
Tarihî dönemlerde tercüme edilmiş farklı metinlere bakıldığında Arapçadaki fiil icracılarını belirtecek değişik şekillerin tercih edildiği anlaşılıyor. Anadolu sahasında Kur'an'ı tercüme etmeye çalışan biri, Karahanlı veya Harezm tecrübesinden haberdar olsaydı oradaki ifade şekillerinden faydalanma yoluna giderdi. Allah'ın sıfatları ve fiillerin karşılı̆̆ı olarak amel-cezamükâfat ilişkisi gibi hassas konularda türetilen var olan veya yeni ifade şekillerini kullanabilirdi. Kendisinden önce bulunmuş karşılıkları rahatça kullanıp işini kolaylaştırması mümkün olabilirdi. Ayrıca açacağı yolun kendinden sonra sürekli kullanılacağı ve yapılabilecek bir yanlışlığın bütün bir toplum tarafından uzun yıllar tekrarlanacağı gibi bir vebalin de farkındaydı. Bütün bunların ötesinde yeni ifade şekilleri arandığına göre Anadolu sahasındaki mütercimlerin kendilerinden önceki tecrübelerden habersiz oldukları rahatça söylenebilir. İnsan hayatının en mühim yönlendiricisi olan dinin temel kitabının tercümesi en çok aranan metin olacaktır. Yazı dilinin bilinmesi hâlinde Kur'an'ın Türkçeye tercümesinin Karahanlı devrindeki gayretleri Anadolu sahasında makes bulurdu. Çünkü dinî metinlerin dili, yanlışa düşme ve yanlışa sevk etme endişesinden dolayı kolay kolay değiştirilmez. Anadolu sahasındaki ilk dönem tercümelerinde Karahanlı tecrübelerinin izine rastlanmadığından yazı dilinde devamlılığın olduğu görüşü Kur'an tercümeleri bağlamında destek bulamaz.

Ahmet Topaloğlu, ${ }^{4}$ Murat Küçük, ${ }^{5}$ Esra Karabacak, ${ }^{6}$ Mustafa Toker ${ }^{7}$ isimli araştırmacıların çalıştıkları Eski Anadolu Türkçesinin ilk Kur'an tercümelerinde ${ }^{8}$ söz konusu fiil icracıları için düşünülen yapı neredeyse müşterektir. Son iki (Karabacak ve Toker) tercümede ${ }^{9}$ daha farklı ifade şekilleri belirse de büyük oranda önceki iki metinle ortaklık gözlemlenmektedir. Karahanl $1^{10}$ ve Harezm Türkçesi ${ }^{11}$ Kur'an tercümelerinde ise hem kendi aralarında bir takip seyrinin bulunmadığı hem de Anadolu sahasıyla herhangi bir ifade şekli üzerinde ittifaklarının olmadığı görülmektedir. Buradan Anadolu sahasında tercümeleri kaleme alanların birbirlerinin metinlerinden haberdar oldukları, Karahanlı ve Harezm sahasındakilerin ise sadece ilgili çevreler tarafından bilinip okunduğu, başka tecrübelere rehberlik etmedikleri anlaşılmaktadır. ${ }^{12}$

4 Ahmet Topaloğlu, 14. Yüzyılın Ortalarında Yapılmış Satırarası Kur'an Tercümesi 1 (İstanbul: Dergâh Yay., 2018).

5 Murat Küçük, Eski Anadolu Türkçesi Dönemine Ait Satır Arası İlk Kur'an Tercümesi (Ankara: TDK Yay., 2014).

6 Esra Karabacak, An Inter-linear Translation of The Qur'an Into Old Anatolian Turkish I-II-III-IV-V-VI-VII-VIII (Harvard Ün., Yakındoğu Dilleri Böl., 1994).

7 Mustafa Toker, Anonim Satır Altı Kur'an Tercümesi (Konya: Selçuk Üniversitesi Basımevi, 2011).

8 Topaloğlu, 14. Yüzyılın Ortalarında Yapılmış Satırarası Kur'an Tercümesi 1, Küçük, Eski Anadolu Türkçesi Dönemine Ait Satır Arası Illk Kur'an Tercümesi.

9 Toker, Anonim Satır Altı Kur'an Tercümesi. Karabacak, An Inter-linear Translation of The Qur'an Into Old Anatolian Turkish I-II-III-IV-V-VI-VII-VIII.

10 Suat Ünlü, Karahanlı Türkçesi İlk Satır-Arası Kur'an Tercümesi (TİEM 73).

11 Gülden Sağol, An Inter-linear Translation of The Qur'an Into Khawarizm Turkish I-II-III-IV-V (Harvard Ün. Yakındoğu Dilleri Böl., 1993).

12 Borovkov'un çalıştığı Kur'an tefsirinin sözlüğündeki kelimelerin de Ünlü ve Sağol metinlerindekilerle herhangi bir koşutluğa sahip olmadığı görülmektedir. A. K. Borovkov, Orta Asya'da Bulunmuş Kur'an Tefsirinin Söz Varlı̆̆ı (XII.-XIII. Yüzyıllar), çev. H. İ. Usta-E. Amanoğlu (Ankara: TDK Yay., 2002). 


\subsection{Arapçadaki Fiil İcracılarının Türkçede İfadesi Meselesi ve "-IcI” Eki}

Eski Anadolu sahasında üretilen Kur'an tercümelerinde Arapçanın ism-i fail, sıfat-1 müşebbehe ve mübalağalı ism-i fail gibi farklı kalıpları için özel karşılık bulma çabasının varlığını söz konusu kalıplar için -IcI ekiyle türetilmiş kelimelerde görmek mümkündür. Eski Anadolu Türkçesinin Kur'an tercümeleri haricindeki metinlerdeki ve Eski Türkçedeki kullanım sıklıklarına bakıldığında nadir görülen eklerden biri olan "-IcI" (<“-ĠUçI") ekini Gabain, "işi yapanı bildirirler"13 şeklinde kısaca tanımlarken Ergin (2008:191), "Türkçede eskiden beri kullanılan çok işlek fiilden isim yapma eki” diye tarif etmiştir. Ekin varlığı Eski Türkçeden beri bilinmekle beraber Ergin' in temas ettiği “çok işlek” olma durumu Eski Türkçe için -Kutadgu Bilig istisna- geçerli değildir. Timurtaş eki, "maharet" ve "itiyad" kelimeleri ile tanımlamaktadır. ${ }^{14}$ Onun bu ifadeleri, Arapçadaki sıfat-ı müşebbehe ve mübalağalı ism-i faile denk düşen kelimeleri tarif etmektedir.

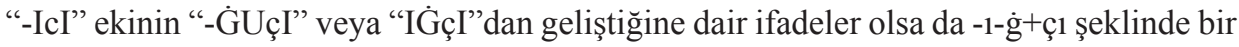
kalıplaşmanın oluşması zor gözükmektedir. Çünkü -Ġ eriyip kaybolsa da işlevini “-I” yardımcı sesi yüklenmiştir. Böylece yeni bir fiilden isim yapım eki olarak görevini sürdürmektedir. "+CI" da isimden isim yapım eki olarak kullanılmaya devam etmektedir. Dolayısıyla bu anlamda bir kalıplaşmadan söz edilemez. Türkiye Türkçesinin tarihî veya çağdaş kullanımlarında "-IcI" ekiyle türetilmiş kelimelerde isme dönük bir anlam durumu gerçekleşmemektedir. Mesela yapıcı kelimesine bakıldığında "yap-1+c1=inşaat ustası, tamirci” gibi bir anlam veya çağrışım oluşmamaktadır. Türkiye Türkçesindeki “yap+1cı” kelimesi doğrudan doğruya "yap-” fiilinin mecazı üzerinden anlam yüklenmektedir. Keza sevmek fiilinden türetilmiş "sevici” kelimesi "sevi-ci=âş̧ık" manasında değil sevme işini çok icra eden kişi anlaşılır, kalıplaşmış anlamıyla bilinen sevici ${ }^{15}$ kelimesi de sevmek fiiline atfen türetilmiştir. "-IcI"nın eklendiği kelimede anlam oluşurken fiilden türemiş isme değil doğrudan fiil kök veya gövdesine bağlanmaktadır. Dolayısıyla "-IcI” ekinin gelişmesi "-I-Ġ+çI”dan değil "-ĠUçI”dandır.

Tarihî metinler tarandığında “-ĠUçI”nın çok işlek bir ek olmadığı anlaşılmaktadır. İlk olarak Orhun Yazıtları'ndaki iki kullanım zikredilebilir: Yapan eden, usta anlamlarında kullanılan “itgüçi”"16 ve bir de sözcü, müşavir anlamlarında kullanılan "ayġuçı"17 kelimelerinde görülür. Eski Uygur Türkçesinde de söz konusu ekle türetilmiş kelime sayısı sınırlıdır, dolayısıyla yaygın bir kullanım alanı yoktur. Kuanşi İm Pusar' da "birgüçi”, "eşitgüçi", ${ }^{18}$ Uygurca Altun Yaruk'ta "yarlıkaguçı". ${ }^{19}$ Ceval Kaya'nın yetmiş binden fazla kelime tespit ettiği Altun Yaruk metninde üç farklı cümlede sadece "yarlıka-" fiilinde bulunmaktadır. Altun Yaruk 3. Kitap’ta

13 Anamarie Gabain, Eski Türkçenin Grameri, çev. Mehmet Akalın, (Ankara: TDK Yay., 1988), 52.

14 F. Kadri Timurtaş, Osmanlı Türkçesi Grameri (İstanbul: Alfa, 1985), 431.

15 Bk. TDK Türkçe Sözlük, sevici maddesi. https://www.sozluk.gov.tr/

16 Muharrem Ergin, Orhun Abideleri (İstanbul: Boğaziçi Yay., 2009), 28.

17 Muharrem Ergin, Orhun Abideleri, 78.

18 Şinasi Tekin, Kuanşi İm Pusar (Ankara: TDK Yay., 1993), 33.

19 Ceval Kaya, Uygurca Altun Yaruk, (Ankara: TDK Yay., 1994), 379/9, 423/13, 436/21. 


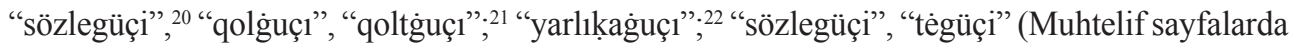
32 defa kullanılmış. Uygurcadaki genel temayüle aykırı olan bu sıklığın sebebi, metnin dil öğretici bir nitelik taşımasındandır ve sadece tè- fiilinde kullanılmaktadır.) ${ }^{23}$

Karahanlı Türkçesi dönemi eserlerinden Atabetü'l-hakayık'ta "atguçı", "kesgüçi”, "öggüçi”, "teggüçi”, ${ }^{24}$ şeklinde dört kelimede görülürken Orta Asya'da Bulunmuş Kur'an Tefsirinin Söz Varlı̆̆ı'nda “aytuçı”, “başlag̉uçı”, “äktülägüçi”, "kitāb ḳoşġuçı”, “oḳı ġuçı”, “oynaġuçı”, "saḳlag̉uçı”, "tapunġuçı”, "yaratg̉uçı”, "yütgüçi”" kelimelerinde ekin kullanımına rastlanır. ${ }^{25}$ Kur'an tefsiri olmasına rağmen sadece 10 kelimenin türetilmesinde bu ekin tercih edilmesi konu bağlamında son derece mühimdir. Dîvânu Lugâti’t Türk'te "agkuçı”, "arḳuçı”, "bititgüçi”, "kapguçı”, "kelgüçi”, “külgüçi”, "közetgüçi”, “ögüngüçi”, “satguçı”, “suwarguçı”, “tapırgçı”, “tepgüçi”, “tirgüçi”, “tograguçı”, “turguçı”, “tutguçı”, “ugraguçı”, “yüküngüçi”26 şeklinde 18 farklı örnekte görülmektedir. Bu rakam yaklaşık $9000^{27}$ kelime arasında sıklık olarak çok düşüktür. Seyfi Sarayi’nin Gülistan’ında "algıcı”, "şi r ḳılg̀ııç”, "ḳısmet ḳılg̀ııçı”, “āzār ḳılġıçı”, “edeb ḳılg̀ıçı” şeklinde ünlü uyumuna ve "tikici” gibi Oğuzcaya tâbi olmuş sınırlı sayıda birkaç örneğe rastlanılmaktadır. ${ }^{28}$

Oğuz Türkçesinin kuruluş devri eserlerine bakıldığında ekin kullanım sıklığı farklılıklar göstermektedir. "-IcI” eki, Âli’nin Klssa-i Yûsuf'unda eserin "karışık dilli” sıfatına uygun "kavuşguçı" ve "kavuşdurıcı" şeklinde bir Karahanlıcaya bir Oğuzcaya tâbi iki örnekte mevcutken Dede Korkut'ta “yıkıcı” şeklinde sadece tek örnekte görülmektedir. ${ }^{29}$ Hatiboğlu'nun Bahrü'l-hakâyık'ında 30 "alıcı", "bekleyici”, “delici”, “isteyici”, "saklayıcı”; Mecmū 'atü'nnezā̄ 'ir'de 31 "ḳan içici”, “yapıcı”; Kitāb-l Güzîde’ de "ögüci”, “dutıcı”, "bakıc1”, “öldürüci”, "sag̉uc1/saġı1”, "saḳlayıc1”, "söyleyici”, "tapıc1”, "tutıc1”, "virici”, "yaratıc1”, "gelici”, “yarıcı” şeklinde kısıtlı sayıda mevcuttur. Yine Yunus Emre Divanı'nda "alıcı”, "sarıcı”, "yalvarıcı", "şeri' at koyıcı", "sevici”, "lutf idici”, "rahm idici”, "bilici”, "isteyici”"32 ve Ahmedî Divanı’nda "ribâ yiyici”, “bizeyici”, “can alıcı”, “yazıc1”, “yanıcı”, “dutıc1”33; Tezkiretü’l-

20 Mehmet Ölmez, Altun Yaruk 3. Kitap (=5. Bölüm) (Beytepe/Ankara, 1991), 111.

21 James, R. Hamilton, Iyi ve Kötü Prens Öyküsü, çev. Vedat Köken (Ankara: TDK Yay., 1998), 14,15,46,48.

22 Özlem Ayazlı, Altun Yaruk Sudur VI. Kitap (Ankara: TDK Yay., 2011), 120.

23 Murat Elmall, Eski Uygurca Dilbilgisi Terimleri (Ankara: TDK Yay., 2017), 99,105, 108.

24 R. Rahmeti Arat, Atabetü'l-hakaylk (Ankara: TDK Yay., 1992).

25 Borovkov, Orta Asya'da Bulunmuş Kur'an Tefsirinin Söz Varlı̆̆ı (XII.-XIII. Yüzyıllar).

26 Ahmet B. Ercilasun, Z. Akkoyunlu, Dîvânu Lugâti’t Türk (Ankara: TDK Yay., 2015).

27 Ahmet B. Ercilasun, Z. Akkoyunlu, Dîvânu Lugâti't Türk, XVII.

28 A. F. Karamanlığlu, Gülistan Tercümesi (Ankara: TDK Yay., 1989).

29 Orhan Ş. Gökyay, Dedem Korkud'un Kitabı (İstanbul: MEB Yay., 1973).

30 Vahit Türk, Bahrü'l-hakâyık (Ankara: TDK Yay., 2009).

31 Mustafa Canpolat, Mecmū 'atü'n-nezāiir (Ankara: TDK Yay., 1982).

32 Mustafa Tatçı, Yunus Emre Divanı, http://ekitap.kulturturizm.gov.tr/Eklenti/10662,girispdf.pdf?0, erişim: 19.5.2019.

33 YaşarAkdoğan, Ahmedî Divanı, http://ekitap.kulturturizm.gov.tr/Eklenti/10591, ahmedidivaniyasarakdoganpdf. pdf?0, erişim: 03.6.2019. 
evliya Tercümesi'nde; "kısmet verici" 34 "tokuyı1", 35 "yol gösterici”, 36 "yol kesici”, ${ }^{37}$ şeklinde vasatın altında bir kullanım sıklığı ile yer almaktadır.

Garibnâme, ${ }^{38}$ Ŏguznâme ${ }^{39} \mathrm{~Hz}$. Ali-İfrit Cenknâmesi, ${ }^{40}$ Kitābu Fė̇ā'ili'l-mekke ve'l-medīne ve'l-kudüs ${ }^{41}$ gibi eserlerde söz konusu ekle türetilmiş kelime bulunmamaktadır.

Eski Anadolu Türkçesi devrinde kaleme alınan bazı eserlerde yüksek sıklıkla kullanılan söz konusu ekin bazı eserlerde çok az kullanılması veya hiç rastlanmaması, ekin yaygınlığıyla izah edilebilir. Dede Korkut ve en son zikredilen erken dönem eserlerinde eke çok az rastlanması Kur'an Arapçası ile münasebetin yaygınlık kazanmadığı anlamına gelir.

Kur'an tercümelerine bakıldığında Arapçadaki fiil icracılarını ifade eden kalıpları karşılamak için Anadolu sahası ile Karahanlı sahasının farklı şekillerden faydalanma yoluna gittikleri görülmektedir. Karahanl1 ${ }^{42}$ ve Harezm ${ }^{43}$ metinlerinin kısmen örtüşen kullanımları, Anadolu ${ }^{44}$ sahasındakilerle büyük oranda farklılık arz etmektedir. Mesela Besmele lafzında bulunan ve Kur'an'da da çok tekrar edilen kelimelerden olan "er-Raḥmān” ve "er-Rahīm”" sıfatları ilk örnek olarak incelenebilir:

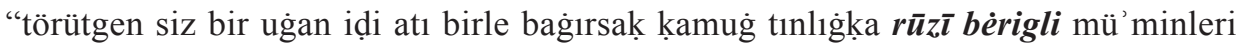
yarlıkagan" 45

“Tangrı birle başlayur men; üküş rahmetli, rahmeti lazım."

"Tayrı adı-y-1la -ya 'nī başların ya okırın- gey rahmat kılıcı, rahmat kılıcı" ${ }^{47}$

Karahanlı döneminde kaleme alınmış olan ve Türk İslam Eserleri Müzesinde muhafaza edildiği için (TIEM 73) olarak bilinen tercümedeki Besmele için verilen karşılık biraz tefsirlidir. Kelimenin anlamını tam verebilmek için uzunca bir izahla birlikte kullanılan "rūzī bėrigli" rạ̣mān'ın, “yarlıḳag̉an” da rahīm'in karşılığıdır. TiEM 73'te zaman zaman fiil icracısı olarak -ĠAn sıfatfiil ekli kelimeler kullanılsa da -ĠlI ile türetilmiş olanlar daha yaygındır. Nitekim hemen altta aynı sıfatların Fatiha suresindeki karşılıkları olarak "er-Raḥmān" için "rūzī bẻrigli" tekrarlanırken "er-Raḥīm” için “yarlıḳag̉lı” şeklinin tercih edildiği görülmektedir.

Harezm Türkçesi Kur'an Tercümesi’nde fiil icracıları için çok düzenli olmasa da -Ġan’lı

34 Serhat Küçük, XVI. Yüzyıla Ait Bir Tezkiretü'l-evliya Tercümesi (İstanbul: Kesit Yay., 2013), 112-115.

35 Küçük, XVI. Yüzyıla Ait Bir Tezkiretü'l-evliya Tercümesi, 204/7, 185.

36 Küçük, XVI. Yüzyıla Ait Bir Tezkiretü'l-evliya Tercümesi, 158.

37 Küçük, XVI. Yüzyıla Ait Bir Tezkiretü'l-evliya Tercümesi, 159.

38 Kemal Yavuz, Garibname (Ankara: TDK Yay., 2000).

39 N. Demir, Ö. Aydoğdu, Oğuzname, (İstanbul: Kesit Yay., 2015).

40 Serhat Küçük, Ali-İfrit Cenknâmesi (İstanbul: Kesit Yay., 2014).

41 Fatih Özek, Kitābu Feżā'ili'l-mekke ve'l-medīne ve'l-ḳdüs (İstanbul: Kesit Yay., 2016).

42 Ünlü, Karahanlı Türkçesi Illk Satır-Arası Kur'an Tercümesi (TIEEM 73).

43 Sağol, An Inter-linear Translation of The Qur'an Into Khawarizm Turkish I-II-III-IV-V.

44 Topaloğlu, 14. Yüzyılın Ortalarında Yapılmış Satırarası Kur'an Tercümesi 1, Küçük, Eski Anadolu Türkçesi Dönemine Ait Satır Arası Illk Kur'an Tercümesi, Karabacak, An Inter-linear Translation of The Qur'an Into Old Anatolian Turkish I-II-III-IV-V-VI-VII-VIII, Mustafa Toker, Anonim Satır Altı Kur'an Tercümesi.

45 Ünlü, Karahanlı Türkçesi İlk Satır-Arası Kur'an Tercümesi (TIEEM 73), 1.

46 Sağol, An Inter-linear Translation of The Qur'an Into Khawarizm Turkish I-II-III-IV-V, 1.

47 Topaloğlu, 14. Yüzyılın Ortalarında Yapılmış Satırarası Kur'an Tercümesi 1, 33. 
yapıların tercih edildiği gözlenmektedir. Besmele'de farklı bir tercih görülse de yaygın olarak zikredilen ek ile türetilmiş kelimeler mevcuttur.

-ĠAn ve -ĠlI ekleri sıfat-fiil olarak kullanıldıklarından sıfat-1 müşebbehe ve mübalağa-i ism-i failler için tam bir karşılık oluşturamadıkları kabul edilmelidir. Anadolu sahasında büyük oranda -An ile karşılanabilecek olan yapıları (-ĠAn ve -ĠlI), nadiren kalıcı isimler yapma kabiliyetine sahip olsalar da Kur'an'ın ifade şeklinin aktarılmasında ikna edici bir anlam alanı oluşturamadıkları düşünülmüş olmalıdır. Ayrıca söz konusu Arapça yapılarla, “Esmaü'l-hüsna” diye bilinen Allah'ın sıfatları da ifade edilir. "Esmaü'l-hüsna"nın sıfatfiille, yani geçici anlam oluşturan bir yapıyla gösterilmesi Allah'ın sıfatlarında, daha doğrusu Allah'a atfedilen fiillerde bir nakısa ortaya çıkaracaktır. Ucu böyle bir nakısaya dönük olan ifade şekli itikaden mahzurlu görülmüş olmalıdır. Bu durumdan kaçınmak için söz konusu yapılarda geçici anlamlar taşıyan sıfatfiiller yerine kalıcı yapılar oluşturan "-IcI" ekini tercih etmişler ve bu eki yaygın ve işlek bir unsura dönüştürmüşlerdir. Nitekim Anadolu sahasında sıfatfiil yerine -IcI ekinin varlığı bunun delilidir. Satır arası tercüme yöntemi kullanıldığından söz konusu ekle türetilen kelimelerin hemen hemen tamamı ism-i fail, sıfat-1 müşebbehe ve mübalağalı ism-i fail kalıplarındaki kelimelerin altına yazılmış durumdadır:

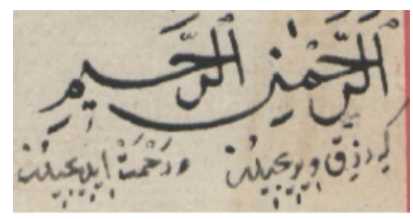

Söz konusu ekin Anadolu sahasındaki ilk dönem Kur'an tercümelerinde ve daha sonraki başka tercüme metinlerde önceki devirlere göre yüksek bir kullanım sıklığına ulaştığ gözlemlenmektedir. Ekin Eski Türkçedeki ve Eski Anadolu Türkçesinin ilk dönemlerindeki kullanım durumu yukarıda gösterilmişti.

XIV. Yüzyılın Ortalarında Yapılmış Satırarası Kur'an Tercümesi'nde ${ }^{48}$ dizin olmadığı için ekin kullanım sıklığı tesbit edilememiştir ancak bu eserin Eski Anadolu Türkçesi Dönemine Ait Satır Arası Illk Kur 'an Tercümesi ${ }^{49}$ ile ifade bakımından büyük oranda koşutluk arz etmektedir. Illk Kur'an Tercümesi'nde Besmele'den başlayarak "rahmat kılıcıdur", 50 "rızk vèricidür", "raḥmet ėdicidür" 51 şeklinde çok yoğun bir -IcI kullanımı görülmektedir. Esra Karabacak'ın hazırladığı Kur'an Tercümesi’nde de aynı yoğunluğu farklı şekillerde görmek mümkündür.

Mesela söz konusu ek ile "bilmek" fiilinden türetilmiş olan "bilici" kelimesinin durumu yayınlanan eserlerde şu şekildedir:

Karabacak'ın dizininde bilmek fiilinden -ici ekiyle türetilmiş 4 "bilici”, 1 "bilici+men”, 2 “bilici+sen”, 1 "bilici+siz”, 1 "bilici+y-idi” ve 171 "bilici+dür” şeklinde toplam 180 kullanım

48 Topaloğlu, 14. Yüzyılın Ortalarında Yapılmış Satırarası Kur'an Tercümesi 1.

49 Küçük, Eski Anadolu Türkçesi Dönemine Ait Satır Arası İlk Kur'an Tercümesi.

50 Topaloğlu, 14. Yüzyılın Ortalarında Yapılmış Satırarası Kur'an Tercümesi 1.

51 Küçük, Eski Anadolu Türkçesi Dönemine Ait Satır Arası İlk Kur'an Tercümesi. 
görülmektedir. Murat Küçük'ün hazırladığg metnin dizininde ise sayı daha yüksek olup aynı ekle türetilmiş 209 "bilici+dür", 13 "bilici”, 1 "bilici+ben”, 1 "bilici+ler", 1 "bilici+men", 1 "bilici+ sen", 1 "bilici+sin" gibi kelimeler toplamda 226 rakamına ulaşmaktadır.

Kur'an-1 Kerim'de birçok defa Allah'ın sıfatı olarak 'alīm, habīr kelimeleri bilen, hakkıyla bilen, her şeyi bilen, haberdar olan gibi anlamlarda kullanılmaktadır. Söz konusu yapılar, Eski Anadolu Türkçesi tercümelerinde "her nesne[y] ${ }^{\mathrm{y}}$ bilicidür" 52 " "Tạrı Ta'ālā siz işledügünizi bilicidür" 53 veya "Dakı Tạrı anı kim işlersiz bilicidür" 54 şeklinde "bilici" kelimesiyle karşılanmıştır. Aynı kelimeler TIEEM 73’te “ol tegme nerseni bilgen ol”"55 ve Harezm’de "ḳamug nerseni bilgen turur" ${ }^{66}$ şeklinde karşılanmıştır.

Yine -ıc1 ekiyle türetilmiş ve yüksek sıklıkta kullanılan "bağışlayıcı" kelimesinin;

Karabacak'ın dizininde 9 "bağışlayıcı", 1 "bağışlayııı+men”, 4 "bağışlayıcı+sen”, 55 "bağışlayıcı+dur” şeklinde toplam 68 defa kullanılırken Murat Küçük'ün dizininde 2 "bağışlayıcı”, 67 "bağışlayıcı+dur”, 2 "bağgşlayıcı+men” olmak üzere toplam 71 defa kullanıldığı görülmektedir.

“bağışlayıcı”nın Karahanlı ve Harezm Türkçelerindeki durumunu birer örnekle görmekte fayda vardır: "Tạrı yazuḳ örtgen yarlıḳagan"57

"ḥaḳiḳat üze Tangrı yarlıḳagan, raḥmet ḳılg̀an"58

Karabacak'ın dizininde “eyleyici” kelimesi, muhtelif isimlerle kurulmuş birleşik fiillerden türetilmiş olarak 654 kere kullanılmıştır.

Yukarıda bazı örnek kullanımları verilen “-IcI” ekinin Eski Anadolu Türkçesi devrinde kaleme alınmış metinlerde az kullanıldığı hatta bazen hiç kullanılmamış olduğu görülürken Kur'an tercümelerinde bu kadar fazla kullanılmasının sebebi, mütercimlerin fiil icracılarını Arapçadaki gibi vazıh bir şekilde ifade etme çabalarından kaynaklandığını söylemek yanlış bir hüküm olmaz. Bu çabaların neticesinde daha sonraki devirlerde ekin kullanım alanı çok genişlemiş, bugünkü Türkiye Türkçesinde en yaygın fiilden isim yapma eki olarak kullanılır duruma gelmiş ve tabiri caizse Türkçenin ism-i faili, sıfat-1 müşebbeheyi gösteren eki olmuştur. Arapçadaki fiil icracılarını gösteren yapıları, bu şekilde titiz ve dikkatlice tercüme çabaları Türkçeyi fiili icra edeni önemseyen bir dil durumuna getirmiştir. Bugün mesela yazmak fiiline bakıldığında; yazan, yazar, yazıcı, yazman, kâtip (kâtibe), muharrir, müellif, müstensih, vakanüvis, sekreter ve hattatla birlikte Türkçenin, yazmak fiilini icra eden kişiyi gösteren on civarında farklı isme sahip bir dil durumuna geldiği görülür.

Karahanlı ve Harezm sahalarına bakıldığında fiil kökenli bir isim kullanılacaksa -IcI yerine -ĠAn ve -ĠlI sıfat-fiil eklerinin tercih edildiği lâkin Anadolu sahasındaki kadar düzenli ve titiz

52 Küçük, Eski Anadolu Türkçesi Dönemine Ait Satır Arası İlk Kur'an Tercümesi, 97.

53 Toker, Anonim Satır Altı Kur'an Tercümesi, 112.

54 Topaloğlu, 14. Yüzyılın Ortalarında Yapılmış Satırarası Kur'an Tercümesi 1, 54.

55 Ünlü, Karahanlı Türkçesi İlk Satır-Arası Kur'an Tercümesi (TİEM 73), 12.

56 Sağol, An Inter-linear Translation of The Qur'an Into Khawarizm Turkish I-II-III-IV-V, 1993, 6.

57 Ünlü, Karahanlı Türkçesi İlk Satır-Arası Kur'an Tercümesi (TİEM 73), 71.

58 Sağol, An Inter-linear Translation of The Qur'an Into Khawarizm Turkish I-II-III-IV-V, 1993, 19. 
bir karşılık bulma çabasının gösterilmediği anlaşılmaktadır. Birkaç yerde Anadolu sahasında olduğu gibi - $\dot{\boldsymbol{G}} \boldsymbol{U} \boldsymbol{c} \boldsymbol{I}$, hatta -IcI ekinin kullanıldığ

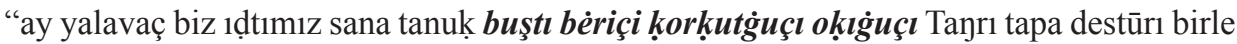
yaruk çerā.

Aşağıda fail isimlerinin farklı surelerdeki kullanımları karşılaştırmalı olarak görülmektedir:

Yukarıda işaret edildiği gibi Besmele ve Fatiha suresindeki aynı lafzın farklı ifadelerle tercüme yoluna gidilmesi, "er-rahīm”" sıfatının Türkçedeki karşılığı konusunda yaşanan tereddüdden kaynaklanıyor olmalıdır. Bakara suresindeki Besmele'de ise "er-raḥmān" ve "errahīm" için biraz tefsir katılmış ve "kamug tepreniglilerke" ilavesiyle "-gli" yerine "-gen" tercih edilmiş, bağışlamak fiili de "-daçı” eki tercihiyle farklı bir anlam düşünülerek çevrilmiştir. Bağışlamak fiili için dünya ile birlikte belki ahiret yönü hesaba katılarak ve gelecek zaman anlamı gözetilerek farklı karşılık düşünülmüştür: "rūzī bergen anar kertgünün seni yarlıḳadaçı." ${ }^{0}$

Kur'an-1 Kerim'deki fiil icracılarının hangi tarihî lehçede hangi şekillerle karşılandığı aşağıda değişik örneklerle gösterilmiştir. Karahanlı Türkçesinde -ĠlI, Harezm Türkçesinde ise -ĠAn ekinde bir yoğunlaşma göze çarpmaktadır; ancak söz konusu Arapça yapıların karşılığında aynı ekle türetilmiş kelimeleri görmek her zaman mümkün olmamaktadır. Buna karşılık Eski Anadolu Türkçesinde -IcI ekiyle türetilmiş kelimeler, büyük oranda fiil icracılarını gösteren kalıplar için kullanılmaktadır. Söz konusu kalıplar her zaman -IcI ekli yapılarla karşılanmasalar da özellikle Topaloğlu ve Küçük'ün yayımladığı Kur'an tercümelerinde -IcI ekli yapılar, daima Kur'an metnindeki ism-i fail, sıfat-ı müşebbehe ve mübalağalı ism-i failler için kullanılmıştır.

\subsection{Arapça Fiil İcracılarının Türkçe Kur'an Tercümelerindeki Durumlarına Örnekler}

Aşağıda değişik fiillerin Karahanlı, Harezm ve Anadolu sahalarında Arapçanın mezkûr yapıları için kullanılan karşılıklarına yer verilmiştir. Muhtelif ayetlerin örnek çevirileri mukayeseli olarak gösterilmiştir:

Bakara suresi 11-12. ayetler

(müfsidîn)

(müfsidîn)

“ḳaçan ayġıl anlarḳa artaḳlık ḳılmạlar yer içinde ayturlar bütünlükün biz edgü kıllığlılar miz." "bilgil kim anlar artak iş kılıglllar yok kim tutmaslar."

“Taḳı ol vaḳtın kim aytıldı anlarg̉a: "Fesād ḳılmang yirde"; aydılar: "Haḳ̣̣̂̂at üze biz

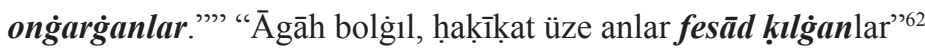

"Dakı kaçan eyidildi anlara: "Fesad eylemen yirde", eyittiler: "Degülüz illâ biz eyü isleyiciler."” "Bayık anlar fesad eyleyicilerdür"63

59 Ünlü, Karahanlı Türkçesi İlk Satır-Arası Kur'an Tercümesi, 3: 217.

60 Ünlü, Karahanlı Türkçesi İlk Satır-Arası Kur'an Tercümesi (TIEM 73), 1:3.

61 Ünlü, Karahanlı Türkçesi İlk Satır-Arası Kur'an Tercümesi (TİEM 73), 1: 6.

62 Sağol, An Inter-linear Translation of The Qur'an Into Khawarizm Turkish I-II-III-IV-V, 2.

63 Topaloğlu, 14. Yüzyılın Ortalarında Yapılmış Satırarası Kur'an Tercümesi 1, 35. 
“daḩı ḳaçan eydülse anlara fesād eylemeyüz yẻrde eydürler biz degülüz illā muṣlīḥlardan" "bilmiş olunuz kim anlar fesād eyleyicilerdür" 64

\section{Bakara suresi 16. ayet}

(mühtedîn)

“anlar tururlar anlar satg்ın aldılar yolsuzluḳnı köni yol birle. asığlıg bolmadı satığçılıḳları bolmadılar köni yolka könügliler."

“Anlar kim satg̉ın aldılar azmaḳnı köni yol birle taḳı asıg ḳılmadı anlarnıng bāzerganlıḳı. taḳ1 bolmadılar köngenler." "66

"Şunlar anlardur kim satun aldılar azgunlığı toğru yol-ıla; pes assı eylemedi bezirgenlikleri; dakı olmadılar toğru yol tutıcılar."

\section{Bakara suresi 53. ayet}

\section{(el-Furkân)}

“ançada bẻrdimiz mūsāḳa bitigni çınnı bāṭıldın adrı่̀lı bolg̀ay kim siler köni yollug̉ bolg̀ay siler." 68

“Taḳı ol vaḳtın kim birdük Mūsāga kitābnı taḳı ayırt kemişgenni"

“Daḳı ol vaḳıt kim virdük Mūsā’ya Tevrit'i daḳı ayırıcıyı -yản̄̄ Tevrit'i kim hakḳı bāṭıldan ayurur..."

“Zikr eylenüz ol güni ki Musā’ya kitāb virdük, hakkı bāṭıldan ayırıcı hükümler virdük"’1 "Şunı da bilin ki biz Mūsāya ḥaḳḳıla bāṭılı farḳ idici hüccet virdik"”2

\section{Kasas Suresi 15. ayet \\ (muḍill)}

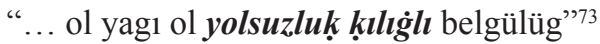

“... bu iblīs işindin; ol düşman azdurgan"

"Uşbu şeyțan işindendür; bayıḳ ol düşmandur, azdurıcıdur bellü." 75

"Taḥḳị̄ şeyțān ulu düşmandur, azdurucı zāhirdür 'adāveti"’76,

“... bu şeytan işi-y-idi. Taḥḳị ol azdurıcı, ulu düşmandur, didi."

Gerek Anadolu gerekse Karahanl1-Harezm sahasında fiillerde ortak kullanım gözlenmektedir. Oranlamak gerekirse Karahanlı-Harezm sahalarında birbirine yakınlık Anadolu sahasından

64 Küçük, Eski Anadolu Türkçesi Dönemine Ait Satır Arası İlk Kur'an Tercümesi, 87.

65 Ünlü, Karahanlı Türkçesi İlk Satır-Arası Kur'an Tercümesi (TİEM 73), 7.

66 Sağol, An Inter-linear Translation of The Qur'an Into Khawarizm Turkish I-II-III-IV-V, 4.

67 Topaloğlu, 14. Yüzyılın Ortalarında Yapılmış Satırarası Kur'an Tercümesi 1, 35.

68 Ünlü, Karahanlı Türkçesi İlk Satır-Arası Kur'an Tercümesi (TIEM 73), 19.

69 Sağol, An Inter-linear Translation of The Qur'an Into Khawarizm Turkish I-II-III-IV-V, 7.

70 Topaloğlu, 14. Yüzyılın Ortalarında Yapılmış Satırarası Kur'an Tercümesi 1, 37.

71 Karabacak, An Inter-linear Translation of The Qur'an Into Old Anatolian Turkish I-II-III-IV-V-VI-VII-VIII, 7.

72 Toker, Anonim Satır Altı Kur'an Tercümesi, 96.

73 Ünlü, Karahanlı Türkçesi İlk Satır-Arası Kur'an Tercümesi (TİEM 73), 3: 120.

74 Sağol, An Inter-linear Translation of The Qur'an Into Khawarizm Turkish I-II-III-IV-V, 214.

75 Topaloğlu, 14. Yüzyılın Ortalarında Yapılmış Satırarası Kur'an Tercümesi 1, 281.

76 Karabacak, An Inter-linear Translation of The Qur'an Into Old Anatolian Turkish I-II-III-IV-V-VI-VII-VIII, 228.

77 Toker, Anonim Satır Altı Kur'an Tercümesi, 309. 
daha fazladır. Zaman zaman Harezm'in Anadolu ile ortaklaştığı, Karahanlı Türkçesinin ayrı düştüğü çeviriler de söz konusudur. Yukarıdaki örneklerde Karahanlı ve Anadolu sahalarında tamlaması karşılığında “az-" fiilinden türetilmiş kelimeler tercih edilirken ${ }^{78}$ Harezm sahasında "yolsuzluḳ ḳılığlı" ifadesinin tercih edildiği görülmektedir.

Sāffāt suresi 99. ayet

(zâhib)

"Taḳı aydı: "men bargan men İdim tapa, köndürgey mini"”79

"men barıg $\boldsymbol{l} \boldsymbol{\imath}$ men iḍim tapa munu körkitgey mana"80

"Daḳı eyitti İbrāhim: "Bayıḳ ben gidici-ven Çalabumdın yạa tiz yol göstere baya." ",

"Eyitti: taḥḳị men gider-men. Tạrı ta ālāya, baya hidayet virür."

"Ben gider-men Tañrı 'ibādetine. Ola ki baña doġru yol göstere." 83

Enbiyā Suresi 81. ayet

('âlim)

“... erdimiz kamug nerseni biligli $"{ }^{4}$

“... Taḳı irdük tigme bir nirseni bilgenler." 85

“... Daḳı olduḳ her nesneyi biliciler."

"... Biz barça nesneyi bilür biz." 87

“... Dahı biz barça nesne ${ }^{\mathrm{y}}$ bilür-biz.."

Nisâ suresi 161. ayet

(elîm)

“anuttımız tanığlılarḳa anlardın a $\dot{g} r ı t ı \dot{g} l \boldsymbol{l}$ ḳınnı"89

"Taḳı anuḳ ḳılduḳ kāfırlarg̉a anlardın, ḳın iglig"90

“... Dakı yarakladık kâfirlar-ıçun anlardan, azab ăgrıdıcı."

“... Taḥḳ̄ị biz yaratduk, yaraḳladuḳ kāfirler-içün anlardan ulu 'azābı ki yürekler yandurucudur." 92

"Dahıı biz yaraḳladuḳ [90a] (1) kāfirlere anlardan yürekleri yandurıcı 'az̄āb."

78 DİB mealinde “ayartıcı" karşılığı uygun görülmüş: https://kuran.diyanet.gov.tr/tefsir/Kasas-suresi/3266/14-17ayet-tefsiri, erişim 20.09.2019

79 Sağol, An Inter-linear Translation of The Qur'an Into Khawarizm Turkish I-II-III-IV-V, 250.

80 Ünlü, Karahanlı Türkçesi İlk Satır-Arası Kur'an Tercümesi (TİEM 73), 3: 297.

81 Topaloğlu, 14. Yüzyılın Ortalarında Yapılmış Satırarası Kur'an Tercümesi 1, 321.

82 Karabacak, An Inter-linear Translation of The Qur'an Into Old Anatolian Turkish I-II-III-IV-V-VI-VII-VIII, 267.

83 Toker, Anonim Satır Altı Kur'an Tercümesi, 345.

84 Ünlü, Karahanlı Türkçesi İlk Satır-Arası Kur'an Tercümesi (TIEEM 73), 2: 388.

85 Sağol, An Inter-linear Translation of The Qur'an Into Khawarizm Turkish I-II-III-IV-V, 178.

86 Topaloğlu, 14. Yüzyılın Ortalarında Yapılmış Satırarası Kur'an Tercümesi 1, 243.

87 Karabacak, An Inter-linear Translation of The Qur'an Into Old Anatolian Turkish I-II-III-IV-V-VI-VII-VIII, 189.

88 Toker, Anonim Satır Altı Kur'an Tercümesi, 275.

89 Ünlü, Karahanlı Türkçesi İlk Satır-Arası Kur'an Tercümesi (TİEM 73), 1: 232.

90 Sağol, An Inter-linear Translation of The Qur'an Into Khawarizm Turkish I-II-III-IV-V, 73.

91 Topaloğlu, 14. Yüzyılın Ortalarında Yapılmış Satırarası Kur'an Tercümesi 1, 76.

92 Karabacak, An Inter-linear Translation of The Qur'an Into Old Anatolian Turkish I-II-III-IV-V-VI-VII-VIII, 56.

93 Toker, Anonim Satır Altı Kur'an Tercümesi, 148. 
Nisâ suresi 162. ayet

(muḳ̂im), (mu’tun), (mu’min)

“mında öndüy aḍkı̣ı tutuġlılar namāz bẻrinler zekātnı kertgünügliler tạrıḳa keḍinki künke"94

“... Taḳı kulganlar namaznı taḳı birgenler zekātnı taḳı bitgenler Tạrığa taḳı ḳıyāmet küninge; anlar, birgeymi anlarg̉a sevāb uluğ"95

“... Dakı tururıcılar namâzı; dakı viriciler zekâtı, dakı inanıcılar Tanrı’ya"96

"zekât virürler, iman getürürler..."97

Şûrâ suresi 22. ayet

(zâlim), (müşfiḳ), (vâḳi`)

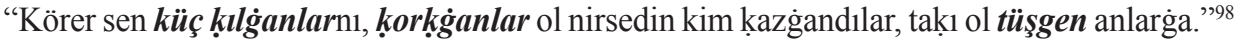

"körgey sen kü̈ç kılıglılarnı korkuglılar anındın kazgandılar ol tüşügli turur anlarka"99

“Göresin zâlımları, korkıcılar andan kim işlediler, dakı düşicidür anlara."100

“Görürsün ẓālimleri korḳarlar kesb eyledükleri yaman 'amellerden”"101

Tevbe suresi 112. ayet

(tâib), ('âbid), (ḥâmid), (sâiḥ), (râki'), (sâcid), (âmir), (nâhûu), (ḥâfiz)

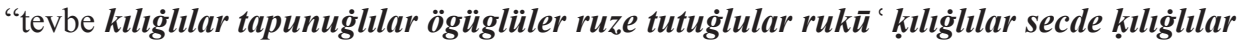
fermanlaġlılar edgülügnü yı

“Tevbe kılganlar, kulluk kılganlar, öggenler, rūze tutġanlar, rükü' kılganlar, secde

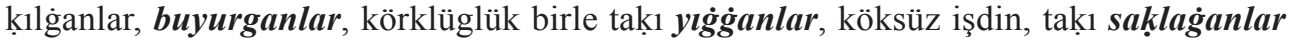
Tangrınıng hadlerin." 103

"Tevbe eyleyiciler, ibâdet eyleyiciler, ögiciler her halda, oruç dutıcılar, -yâ gazâya, yâ ilm okuyı varıcılar-, rüku' eyleyiciler, buyurıcılar eyü işi, dakı yı̆̆ıcılar yavuz işden, dakı saklayıcılar Tanr1 hadlarını"104

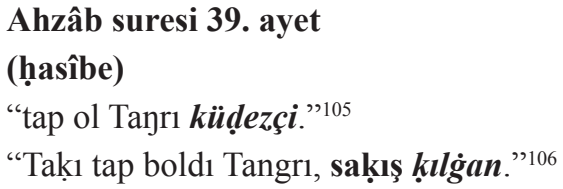

94 Ünlü, Karahanlı Türkçesi İlk Satır-Arası Kur'an Tercümesi (TIEM 73), 1: 232.

95 Sağol, An Inter-linear Translation of The Qur'an Into Khawarizm Turkish I-II-III-IV-V, 55.

96 Topaloğlu, 14. Yüzyllın Ortalarında Yapılmış Satırarası Kur'an Tercümesi 1, 96.

97 Karabacak, An Inter-linear Translation of The Qur'an Into Old Anatolian Turkish I-II-III-IV-V-VI-VII-VIII, 56.

98 Sağol, An Inter-linear Translation of The Qur'an Into Khawarizm Turkish I-II-III-IV-V, 272.

99 Ünlü, Karahanlı Türkçesi İlk Satır-Arası Kur'an Tercümesi (TIEEM 73), 404.

100 Topaloğlu, 14. Yüzyılın Ortalarında Yapılmış Satırarası Kur'an Tercümesi 1, 345.

101 Karabacak, An Inter-linear Translation of The Qur'an Into Old Anatolian Turkish I-II-III-IV-V-VI-VII-VIII, 290.

102 Ünlü, Karahanlı Türkçesi İlk Satır-Arası Kur'an Tercümesi (TIEM 73), 2: 40.

103 Sağol, An Inter-linear Translation of The Qur'an Into Khawarizm Turkish I-II-III-IV-V, 107.

104 Topaloğlu, 14. Yüzyllın Ortalarında Yapılmış Satırarası Kur'an Tercümesi 1, 158.

105 Ünlü, Karahanlı Türkçesi Illk Satır-Arası Kur'an Tercümesi (TIEM 73), 2: 215.

106 Sağol, An Inter-linear Translation of The Qur'an Into Khawarizm Turkish I-II-III-IV-V, 235. 
"Dakı tap old1 Tanrı, hisâb eyleyici -yâ arḳa virici-"107

"Yitişür Tārı ta'ālā hisāb eyleyici"'108

Şûrâ suresi 23. ayet

(ġafûr), (şekûr)

"bütünlükün Tayrı yazuk örtgen üküş yanut bergen." 109

"ḥaḳiḳat üze Tangrı yarlıkagan, şükr kıligan."110

"Bay1ḳ Tayrı yarlı̆̆ayıcıdur, müzd viricidür şükre."111

"Taḥḳ̄k Tạrı ta ālā 'afv eyleyicidür yamanlığı, şükr eyleyicidür muti' olanları..."112

"Tạrı ta ālā günahlar bağışlayıcıdur."113

Neml suresi 80. ayet

(mudbir)

"sėn ėşittürmes sėn ölüglerke. ėşittürmes sẻn ürlerke oḳımaḳnı ḳaçan kim ewrülmesler arḳa bérigliler.” 114

“Taḳı işittürmezsen sen saġırlarg̉a ündemekni, ol vaḳtın kim yüz ewürdiler i rāż ḳılı́glı bolup." "115

"Bayık sen işitdürmeyesin ölülere, dakı işitdürmeyesin sağırlara okımaklığı îmâna, ol vakıt kim yüz döndürdiler, yüz döndüricilerken."116

\subsection{Karahanlı-Harezm Sahası Kur'an Tercümelerinde -ĠUçI Ekinin Durumu}

-ĠUçI eki, fiillerden icra eden kişiyi gösteren kelimeler türeten bir ek olarak nadir kullanım sıklığını Karahanlı ve Harezm sahasında yapılmış Kur'an tercümelerinde de korumuş durumdadır. Borovkov'un hazırladığg sözlükte toplam on kelimede görülen ek Ünlü ${ }^{117}$ ve Sağol'da da düşük yoğunluktadır. Ahzab suresi, 45. ayetin tercümesinde kullanılan "buştı bėriçi", "ḳorḳutġuçı" ve "oḳığuçı" karşılıkları Eski Anadolu Türkçesi çevirileri ile tercih edilen fiillere kadar tam bir koşutluk arz etmektedir. Çok nadir rastlanan bu durum, "buştı bėriçii"deki (="muştu vèrici") Oğuzcanın etkisi bakımından da dikkat çekmektedir. Taramalar sırasında rastlanan "-ĠUçI" ekli örnekler ve Karahanlı ve Harezm sahası tercümelerindeki durumları aşağıdadır:

\section{Ahzâb suresi 45-46. ayet \\ (mübeşşir), (nezîir), (munîr)}

“ay yalavaç biz ıḍtımız sana tanuḳ buştı bẻriçi ķorḳutg்uçı oḳığuçı Tạrı tapa destūrı birle

107 Topaloğlu, 14. Yüzyılın Ortalarında Yapılmış Satırarası Kur'an Tercümesi 1, 304.

108 Karabacak, An Inter-linear Translation of The Qur'an Into Old Anatolian Turkish I-II-III-IV-V-VI-VII-VIII, 249.

109 Ünlü, Karahanlı Türkçesi İlk Satır-Arası Kur'an Tercümesi (TIEM 73), 3: 405.

110 Sağol, An Inter-linear Translation of The Qur'an Into Khawarizm Turkish I-II-III-IV-V, 272.

111 Topaloğlu, 14. Yüzyılın Ortalarında Yapılmış Satırarası Kur'an Tercümesi 1, 346.

112 Karabacak, An Inter-linear Translation of The Qur'an Into Old Anatolian Turkish I-II-III-IV-V-VI-VII-VIII, 291.

113 Küçük, Eski Anadolu Türkçesi Dönemine Ait Satır Arası İlk Kur'an, 291.

114 Ünlü, Karahanlı Türkçesi İlk Satır-Arası Kur'an Tercümesi (TIEEM 73), 3: 111.

115 Sağol, An Inter-linear Translation of The Qur'an Into Khawarizm Turkish I-II-III-IV-V, 212.

116 Topaloğlu, 14. Yüzyılın Ortalarında Yapılmış Satırarası Kur'an Tercümesi 1, 278.

117 Bakara suresinde sadece iki örnekte "-ĠUçI” görülmektedir. 
yaruk çerāg. ."118

"Biz 1̣̣tuḳ sini tanuḳ taḳı müjde birigli taḳı ḳorḳuglı taḳı ündegli Tangrı tapa āsān ḳılmaḳı birle; taḳ1 yaruk çırā' ’"119

"Bayık biz viribidük seni tanuk dakı muştılayıcı dakı korkıdıcı, dakı okıyıcı Tanrı' dın yaja destûr1-y-1la dak1 çırağ rûşan eyleyici." ${ }^{120}$

Görüldüğü gibi Ünlü’nün ve Topaloğlu'nun neşrettiği tercümelerde buştı bériçi ḳorḳutgiuçı okıı uçı ve muştılayıcı korkıdıcı okıyıcı şeklinde koşut yapılar görülmektedir. buştı bèriçi ifadesinde "-içi”" şeklinin tercih edilmiş olması Oğuzca tesirle izah edilebilir. Çünkü Karahanl1Harezm sahasında ve devamı olan çağdaş Kıpçak ve Karluk lehçelerinde ek "-ĠUçI” şeklindedir.

\section{Âl-i İmrân suresi 55. ayet}

(câ'il)

“Ay Īsā! Men tükel alg̉anıng men; taḳı kötürgening men, menim tapa; taḳı arı̀g ḳılġanıng men, anlardın kim küfr ketürdiler; taḳı anlarnıng kıllg uçısı men kim uydılar sanga ..."’121

TİEM metninde de aynı durum söz konusudur:

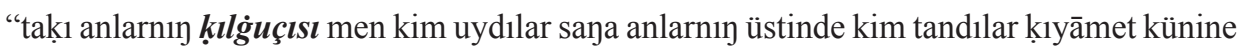
tegin.""122

“İy Îsâ! Bayık ben tamam alıcıvan seni -ya öldüriciven seni -ya'ni gökden girü inicek- dak1 götüriciven seni benüm dapa, dakı arıdıcıvan seni -ya’ni ırak eyleyiciven seni- anlardan kim kâfir oldılar; dakı kılıcıvan anları kim uydılar sana ..."123

\section{Bakara suresi 177. ayet}

(sâil)

"bėrsen tawarnı anın sewüglügi üze yag̉uluḳ iḍilerine atasızlarḳa çıġaylarḳa yol og̉lanınġa

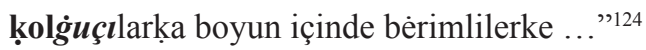

“taḳı birdi mālnı sewmeki üze, yawuḳluḳ eyeleringe taḳı yetimlerge taḳı miskinlerge taḳı

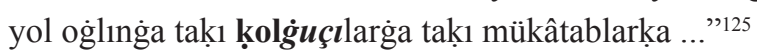

“Dakı virdi malı, malı sever-iken -ya Tanrı'yı sever-iken- hısımlık işlerine dakı yetimlere dakı yol erine dakı dileyicilere, dakı mükâtebeler bahâsına ..."’126

"Malı virmekdür maḥabbeti bile sevmek bile yā Allāh maḥabbetine ḳarayiblere, yetimlere, miskinlere, müsāfirlere, dilencilere, mükātiblere dahı ...."127

“Dahı sadaḳa eylemekdür māl Allāh dostluğuna, ḳarāyiblere daḩı, yetimlere ve miskinlere

118 Ünlü, Karahanlı Türkçesi İlk Satır-Arası Kur'an Tercümesi (TİEM 73), 3: 217.

119 Sağol, An Inter-linear Translation of The Qur'an Into Khawarizm Turkish I-II-III-IV-V, 235.

120 Topaloğlu, 14. Yüzyılın Ortalarında Yapılmış Satırarası Kur 'an Tercümesi 1, 304.

121 Sağol, An Inter-linear Translation of The Qur'an Into Khawarizm Turkish I-II-III-IV-V 32.

122 Ünlü, Karahanlı Türkçesi İlk Satır-Arası Kur'an Tercümesi (TIEM 73), 1:126.

123 Topaloğlu, 14. Yüzyılın Ortalarında Yapılmış Satırarası Kur'an Tercümesi 1, 67.

124 Ünlü, Karahanlı Türkçesi İlk Satır-Arası Kur'an Tercümesi (TİEM 73), 1: 62.

125 Sağol, An Inter-linear Translation of The Qur'an Into Khawarizm Turkish I-II-III-IV-V 17.

126 Topaloğlu, 14. Yüzyılın Ortalarında Yapılmış Satırarası Kur'an Tercümesi 1, 48.

127 Karabacak, An Inter-linear Translation of The Qur'an Into Old Anatolian Turkish I-II-III-IV-V-VI-VII-VIII, 17. 
ve yohsullara, misāfirlere dahı dilencilere ve yesirlere daḩı ... "128

Bakara suresi 249. ayet

\section{(mubtelî)}

"ḳaçan kim aḍrılıp çıḳtı erse țālūt çerig birle aydı bütünlükün Tạrı sınaġuçı ol silerni bir arık birle. ..."129

“Ol vaḳtın kim ayrıldı Ṭālūt çerigler birle; aydı: "Haḳịạat üzre Tangrı sınaġanıngız turur arık birle. ..."130

"Pes ol vaḳt kim çıkdı Tâlût süler-ile -ya’nî seksen bin işsüz yigid-ile eyitti: "Bayık Tạrı sinayıcıdur sizi bir ırmağ-1la. ..."131

"Vaktī ki Ṭālūt ayırdı çerilerini eyitti: Taḥḳ̄ị Tạrı ta âlā ibtilā eyler, sizi tecribe eyler, bir ulu ırmaḳ șuyı, belki aḳar șudur. ..."132

"Pes ol vaḳt kim yürüdi Ṭālūt çeriler bile. Eyitdi: Tạrı Ta'ālā sizi sınayacaḳdur bir ulu 1rmaḳ-1la. ..."133

“-ĠUçI” ekinin günümüz Kur'an tercümelerindeki durumu hakkında ipucu mahiyetinde iki ayetteki örneği zikretmek uygun olacaktır. Afganistan'da kullanılan Özbek Türkçesi Arap harfli yazı dili olarak Özbekistan'daki yazı dilinden ayrılmaktadır. Çağatay Türkçesinin devamı mahiyetindeki bu yazı diliyle yayımlanmış olan bir Kur'an tercümesinde Bakara suresinin 10 ve 11. ayetlerinde (elîm), (mufsid) kelimeleri, aşağıdaki şekillerde karşılanmıştır:

"ve ularning yüreklerige kesellik bar, pes Allah Teâlâ ularning keselligini köp kıldı ve ular üçün aġrıtgüçi azab bar" "agâh bolingler elbette has özleri fesâd kılgüçilerdir velîkin agah bölmeydiler" şeklindedir. Bünyâd-1 Ta'lîmü'l Kur'an-1 Afganistan, 3. s., (28.10.1390)134:

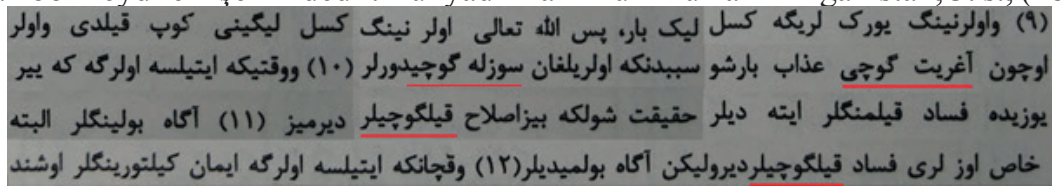

Diğer örnek de aynı ayetlerin Tatar Türkçesindeki durumunu göstermektedir:

“Alarnin künellerindi Allahuga karşılık çire bar, Allah alarnī karşılık çirlerin arttırdı ve alarga ahirette rencitgüçi gazabdir. ..." "Alarga "Yir üstinde bozıklık kılmağı!z" dip eytilse, alar "biz fekat "aralarnı" tüzetgüçigine biz"diyler."135:

128 Toker, Anonim Satır Altı Kur'an Tercümesi, 107.

129 Ünlü, Karahanlı Türkçesi İlk Satır-Arası Kur'an Tercümesi (TIEM 73), 91.

130 Sağol, An Inter-linear Translation of The Qur'an Into Khawarizm Turkish I-II-III-IV-V,23.

131 Topaloğlu, 14. Yüzyılın Ortalarında Yapılmış Satırarası Kur'an Tercümesi 1, 57.

132 Karabacak, An Inter-linear Translation of The Qur'an Into Old Anatolian Turkish I-II-III-IV-V-VI-VII-VIII, 24.

133 Toker, Anonim Satır Altı Kur'an Tercümesi, 115.

134 Bünyâd-1 Ta'lîmü'1 Kur'an-1 Afganistan, Tercüme Özbikî, Afganistan, (28.10.1390), 3.

135 Abdülhasib Moflyuhunov, Nurulla Nazaram, Nogmani Tefsire, (Kazan 2014), 3. 


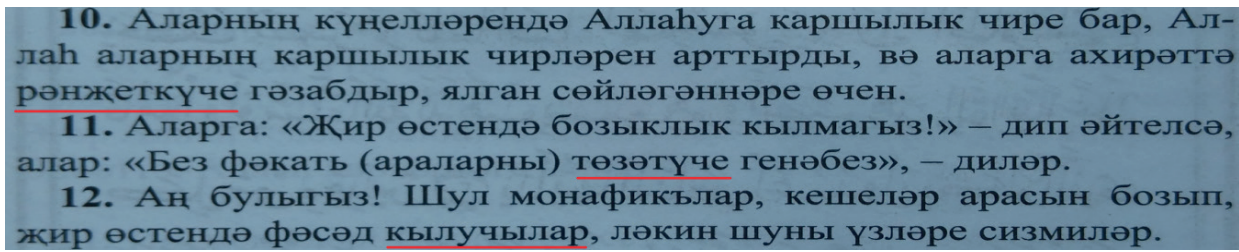

"elîm” için Afganistan Özbek lehçesinde "ag̉rıtgüçi”" Tatar lehçesinde de "rencitgüçi" uygun görülürken Eski Anadolu sahasında "acıdıcı"136 ve "ağrıdıcı"137 kelimeleri kullanılmıştır.

Aynı ayetlerdeki yapılar, Karahanlı, Harezm ve Eski Anadolu sahasında (musliḥ) ve (mufsid)

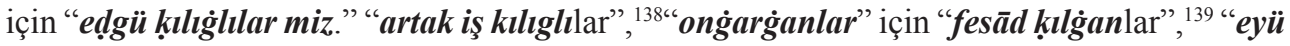
işleyiciler" "fesad eyleyicilerdür"140 "fesād eyleyiciler" (Küçük) şeklindedir. Zikredilen örnekler, tarihî dönem metinleri ile çağdaş lehçelerde bir koşutluk olduğunun ipuçlarını vermektedir. Kesin bir hükme varmak için gerekli olan araştırma bu çalışmanın sınırlarının ötesindedir.

\section{Sonuç}

Türk tarihinde kabaca üç büyük tercüme hareketinden bahsedilebilir. Türkçe Uygurlar döneminde; Budacılık, Manicilik, Brahmanizm gibi dinler ve Sogdca, Sanskritçe ve Çince gibi dillerden yapılan tercümelerle hem hukuk, din gibi farklı alanlarda hizmet veren bir yazı diline sahip olmuş hem de yazılı bir edebî dile kavuşmuştur. Bu dönemde bahsi geçen dillerden yoğun bir şekilde kavram, kelime, anlatım şekilleri ve cümle çeşitleri kazanmıştır. Türkçe İslamiyet' in kabulü ile bu defa Arapça ve Farsça kaynaklı kelime, kavram ve ifade zenginliği yanında birçok yeni edebî türle tanışmıştır. Tanzimat'tan sonra da Fransızca, İtalyanca, Almanca ve İngilizce gibi dillerden Türkiye Türkçesine ve Rusça üzerinden de diğer Türk topluluklarının konuştuğu lehçelere tercümeler yoluyla yeni yeni dil zenginlikleri taşınmıştır.

Orhun, Uygur, Karahanlı, Harezm sahalarında ve Oğuzcanın ilk dönemlerinde çok az kullanım alanına sahip olan "-ĠUçI” (>IcI) ekinin Eski Anadolu Türkçesinin belli bir aşamasından itibaren Türkiye Türkçesinin çok işlek bir eki durumuna gelmesi, ilk dönemlerde Arapçadan, -özellikle Kur'an-ı Kerim- yapılan tercümelerle ilişkilidir. Anadolu Türkçesi yazı dilinin kuruluşu döneminde ve öncesinde yaygın bir kullanıma sahip olmayan -IcI eki, başta Kur'an olmak üzere klasik İslâm metinlerinde Arapçadaki fiil icracılarını gösteren kelime türlerinin Türkçede karşılıklarını arama çabası neticesinde işlek bir ek durumuna yükselmiş ve bu ekle türetilen kelimeler Türkçenin söz varlığına yoğun katk1 sağlamıştır. Aynı zamanda Türkçe, farklı ifade imkânlarına da sahip duruma gelmiştir. Eski Anadolu Türkçesi metinlerinin bazısında çok bazısında az kullanılması bazısında ise hiç olmaması

136 Karabacak, An Inter-linear Translation of The Qur'an Into Old Anatolian Turkish I-II-III-IV-V-VI-VII-VIII., Küçük, Eski Anadolu Türkçesi Dönemine Ait Satır Arası İlk Kur'an Tercümesi.,

137 Topaloğlu, 14. Yüzyılın Ortalarında Yapılmış Satırarası Kur'an Tercümesi 1.

138 Ünlü, Karahanlı Türkçesi İlk Satır-Arası Kur'an Tercümesi (TIEMM 73).

139 Sağol, An Inter-linear Translation of the Qur'an Into Khawarizm Turkish I-II-III-IV-V.

140 Topaloğlu, 14. Yüzyılın Ortalarında Yapılmış Satırarası Kur'an Tercümesi 1. 
erken dönem metinlerinde söz konusu ekin işlek olarak kullanılmadığına işarettir. Arapça, özellikle Kur'an kaynaklı çeviriler çoğaldıkça ve yaygınlaştıkça ek daha tanınır olmuş ve Türkçenin işlek ekleri arasına girmiştir.

“-ĠUçI” eki, Kur’an tercümeleri bağlamında bakıldığında Karahanlı-Harezm sahasında yaygın bir kullanım alanına sahip değildir. Karahanlı Türkçesi Uygur Türkçesinin devamı niteliğinde olduğundan Kur'an mütercimleri Anadolu sahasındaki meslektaşlarına göre daha rahat hareket imkânına sahiplerdi. Eski Anadolu Türkçesini kullanan mütercimler, Oğuzcanın hem yazı dili olarak gelişmesine katkı sağlamışlar hem de Arapça gibi büyük bir dilin en hassas, sanatlı, çok farklı anlatım ve üsluplara sahip metnini Oğuzcaya tercüme çabası göstermişlerdir. Oturmuş bir yazı geleneğine sahip olan Karahanlı-Harezm sahasında Anadolu'daki kadar inceliklerin gözetilmediği, Arapçadaki birtakım yapılar için özel karşılıklar bulma arayışına gidilmediği anlaşılmaktadır.

Çağdaş Türk lehçeleri arasında Karahanl-Harezm yazı dili geleneğinin temsilcisi durumundaki Tatar ve Özbek Türkçelerinde son dönem Kur’an tercümelerinde -güçi ekinin daha sık görünür olması, "Kendi yazı dili geleneğinde ulaşılmış bir sonuç mudur yoksa Osmanlı geleneğinden etkilenme midir?" şeklindeki bir soruyu akla getirmektedir. Bu konu ise ancak başka bir çalışma sonuncunda açıklığa kavuşturulabilecektir.

\section{Kaynaklar}

Akdoğan, Yaşar, Erişim 03.06.2019 http://ekitap.kulturturizm.gov.tr/Eklenti/10591,ahmedidivaniyasarakdoganpdf. pdf?0

Arat, R. Rahmeti. Atabetü'l-hakaylk. Ankara: TDK Yay., Ankara, 1992.

Ayazlı, Özlem. Altun Yaruk Sudur VI. Kitap. Ankara: TDK Yay., 2011.

Borovkov, A. K. Orta Asya'da Bulunmuş Kur'an Tefsirinin Söz Varllğı (XII.-XIII. Yüzyıllar). Çeviren H. İ. Usta-E. Amanoğlu. Ankara: TDK Yay., 2002.

Bünyâd-1 Ta'lîmü'l Kur'an-1 Afganistan, Tercüme Özbikî, Afganistan, (28.10.1390)

Canpolat, Mustafa. Mecmū'atü'n-nezāiir. Ankara: TDK Yay., 1982.

Cin, Ali. Ali'nin Klssa-i Yûsuf'u. Ankara: TDK Yay., 2011.

Demir, N.-Aydoğdu, Ö. Oğuzname. İstanbul: Kesit Yay., 2015.

Develi, Hayati, “Ağız Özellikleri Taşıyan Bir Eski Türkiye Türkçesi Metni Fatiha Tefsiri”, İlmî Araştırmalar, (1998): 63-81 İstanbul.

Elmal1, Murat. Eski Uygurca Dilbilgisi Terimleri. Ankara: TDK Yay., 2017.

Ercilasun, Ahmet B.-Akkoyunlu, Z. Dîvânu Lugâti’t Türk. Ankara: TDK Yay., 2015.

Ergin, Muharrem. Orhun Abideleri. İstanbul: Boğaziçi Yay. 2008.

Gabain, Anamarie. Eski Türkçenin Grameri. Çeviren Mehmet Akalın. Ankara: TDK Yay., 1988.

Gökyay, Orhan Ş. Dedem Korkud'un Kitabı. İstanbul: MEB Yay., 1973.

Hamilton, James, R. İyi ve Kötü Prens Öyküsü. Çeviren Vedat Köken. Ankara: TDK Yay., 1998.

Kaçalin, M. S. Dedem Korkut’un Kazan Bey Oğuznamesi. İstanbul: Kitabevi Yay., 2006. 
Karabacak, Esra. An Inter-linear Translation of The Qur'an Into Old Anatolian Turkish I-II-III-IV-V-VI-VIIVIII. Harvard Ün. Yakındoğu Dilleri Böl., 1994-95-95-99.

Karamanlığlu, A. F. Gülistan Tercümesi. Ankara: TDK Yay., 1989.

Kaya, Ceval. Uygurca Altun Yaruk. Ankara: TDK Yay., 1994.

Korkmaz, Zeynep. Türkiye Türkçesinin Temeli Oğuz Türkçesinin Gelişimi. Ankara: TDK Yay., 2013.

Küçük, Murat. Eski Anadolu Türkçesi Dönemine Ait Satır Arası Illk Kur 'an Tercümesi. Ankara: TDK Yay., 2014.

Küçük, Serhat. XVI. Yüzyıla Ait Bir Tezkiretü'l-evliya Tercümesi. İstanbul: Kesit Yay., 2013.

Küçük, Serhat. Ali-Iffrit Cenknâmesi. İstanbul: Kesit Yay., 2014.

Küçük, Serhat. Kitâb-l Güzîde,. İstanbul: Kesit Yay., 2014.

Moflyuhunov, Nurulla Nazaram. Nogmani Tefsire. Kazan, 2014.

Ölmez, Mehmet. Altun Yaruk 3. Kitap (=5. Bölüm). Beytepe/Ankara,1991.

Özdoğan, M. Akif. “Abbasîler Dönemi Tercüme Faaliyetlerinin Arap Edebiyatına Etkisi”, Nüsha Şarkiyat Araştırmaları Dergisi, 5/16. (2005), Ankara.

Özek, Fatih. Kitābu Feżā'ili'l-mekke ve'l-medīne ve'l-ḳudüs. İstanbul: Kesit Yay., 2016.

Sağol, Gülden, An Inter-linear Translation of The Qur'an Into Khawarizm Turkish I-II-III-IV-V, Harvard Ün. Yakındoğu Dilleri Böl., 1993-95-96.

Tatçı, Mustafa, http:/ekitap.kulturturizm.gov.tr/Eklenti/10662,girispdf.pdf?0, Erişim 19.5.2019.

Tekin, Şinasi. Kuanşi Im Pusar, Ankara: TDK Yay., 1993.

Timurtaş, F. Kadri. Osmanlı Türkçesi Grameri. İstanbul: Alfa Yayınları, 1985.

Toker, Mustafa. Anonim Satır Altı Kur'an Tercümesi. Konya: Selçuk Üniversitesi Basımevi, 2011.

Topaloğlu, Ahmet. 14. Yüzyılın Ortalarında Yapılmış Satırarası Kur'an Tercümesi 1. İstanbul: Dergâh Yay., 2018.

Türk, Vahit. Bahrü'l-hakâyık. Ankara: TDK Yay., 2009.

Ünlü, Suat. Karahanlı Türkçesi İlk Satır-Arası Kur'an Tercümesi (TIEEM 73). Konya: Eğitim Kitabevi, 2018.

Yavuz, Kemal. Garibname. Ankara:TDK Yay., 2000. 